\title{
POTENTIAL FOR GENETIC DISCRIMINATION \\ IN ACCESS TO INSURANCE: IS THERE A DARK SIDE TO INCREASED AVAILABILITY OF GENETIC INFORMATION?
}

\author{
ELIZABETH ADJIN-TETTEY*
}

This article addresses the reliance on genetic information as part of the private insurance industry's practice of risk segmentation whereby underwriting decisions are based on risk information about individuals and groups as compared to the general population. The author argues that there are a number of concerns regarding reliance on genetic information in insurance underwriting, including uncertainty about what constitutes genetic information and the predictive value thereof, possible conflicts with human rights values, potential reductions in access to insurance, and the legal and ethical obligations of individuals who undergo testing, health professionals, and insurers. This article reviews the solutions that have been adopted in other jurisdictions and concludes that the use of genetic information is consistent with standard insurance industry practices. However, it is recommended that a legislative framework be established in Canada to regulate the use of genetic information.
Cet article aborde la confiance dans l'information génétique accordée dans le cadre de la pratique de la segmentation du risque du secteur de l'assurance privée. En vertu de cette pratique, les décisions relatives à la souscription sont fondées sur les informations sur le risque que des particuliers et des groupes présentent par rapport à la population générale.L'auteur fait valoir qu'il y a plusieurs préoccupations quant à la confiance accordée à l'information génétique dans les décisions de souscription, dont l'incertitude quant à ce qui constitue information génétique et sa valeur prédictive, les conflits éventuels des valeurs de droits de la personne, les accès réduits à l'assurance et les obligations juridiques et éthiques des personnes qui subissent les analyses, des professionnels de la santé et des assureurs. Cet article examine les solutions adoptées dans d'autres juridictions et conclut que le recours à l'information génétique est conforme aux pratiques en cours dans le secteur de l'assurance. Cependant, il est recommandé d'établir un cadre législatifau Canada dans le but de réguler l'utilisation de l'information génétique.

\section{TABLE OF CONTENTS}

I. INTRODUCTION . . . . . . . . . . . . . . . . . . . . . . . . . . . . . 578

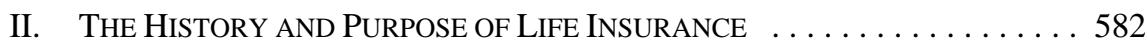

III. Why IS THERE CONCERN ABOUT GENETIC DisCRIMINATION? . . . . . . . . 585

IV. GENETIC INFORMATION . . . . . . . . . . . . . . . . . . . . . . 593

A. SHOUld InSURERS Be ENTITLED TO RELY ON GENETIC

INFORMATION IN MAKING UNDERWRITING DECISIONS? . . . . . . . 593

B. The Predictive VAlue of Genetic Information:

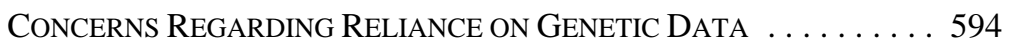

C. GENETIC EXCEPTIONALISM: IS GENETIC INFORMATION

SUFFICIENTLY UNIQUE TO WARRANT DIFFERENT TREATMENT? . . 596

D. The Maximum Utility Argument . . . . . . . . . . . . 600

E. Questions That SHOULD INFLUENCE ReSPONSES

to Concerns About the USE of Genetic Data . . . . . . . . 601

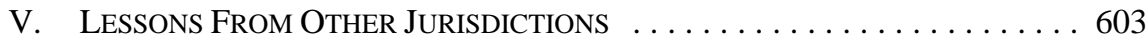

Professor, Faculty of Law, University of Victoria, eadjinte@uvic.ca. This article benefitted from the financial support of the British Columbia Law Foundation. Thanks to Jessica Lo, Natalie Smith, and Melissa Beirnes for their research assistance. 


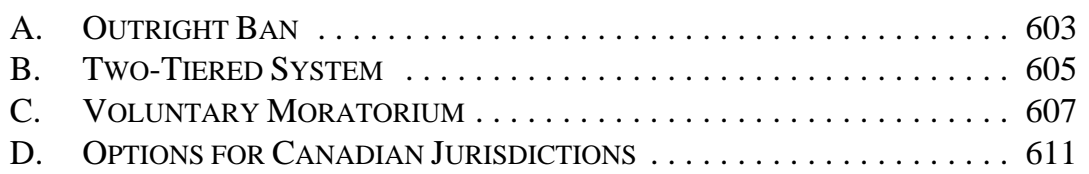

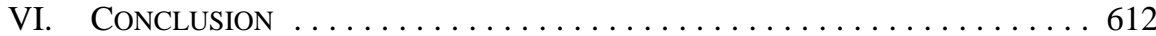

Progress in human genetics has led to fears about genetic discrimination, particularly in insurance and employment, because of the perceived power of human genetics to make predictions about people's future lives — and hence future health insurance risks, time of death, and employment productivity. ${ }^{1}$

\section{INTRODUCTION}

Insurance institutions are part of the new form of governance of risk management in the neo-liberal state grounded in market fundamentalism and minimum state intervention, in which individual responsibility for one's well-being and managing risks is emphasized. Yet, there are limits to individual self-reliance and there is a need to socialize some risks. While collective responsibility for managing risks underlies the welfare state, individuals are increasingly expected to manage risks through market-based mechanisms such as private insurance through the pooling of risks instead of or in addition to state benefits. ${ }^{2}$ Access to private insurance is, therefore, an important public policy objective in the neo-liberal state. In fact, the Canadian Life and Health Insurance Association Inc. (CLHIA) has stated that its members are interested in insuring as many people as possible and not unnecessarily declining insurance coverage to persons who do not pose excessive risks. ${ }^{3}$ Private insurance has become an important mechanism for managing risks and accessing many social goods. Insurance is seen as promoting self-reliance, with a corresponding reduction in reliance on the social security system in the event of misfortune. This is consistent with the expectation of individual responsibility for financial security and well-being for themselves and their dependants in the neo-liberal state, thereby reducing dependency on the welfare state. ${ }^{4}$

Further, while universal health care guarantees all Canadians access to publicly-funded health care, private insurance continues to play an important role as an increasing number of health care services and products are delisted from the publicly-funded system. Although neo-liberalism expects governments to play a minimal role in risk management and to leave individuals to manage their own political economy, there could still be a role for state regulation at a macro level to facilitate the self-governing of individuals. In the context of insurance, this could take the form of regulation regarding the use of certain information in

1 Henry T Greely, “Genotype Discrimination: The Complex Case for Some Legislative Protection” (2001) 149:5 Univ Pa L Rev 1483 at 1484.

$2 \quad$ See Richard Ericson, Dean Barry \& Aaron Doyle, “The Moral Hazards of Neo-Liberalism: Lessons From the Private Insurance Industry” (2000) 29:4 Economy \& Society 532 at 532-33; Chris Armstrong, "Equality, Risk and Responsibility: Dworkin on the Insurance Market” (2005) 34:3 Economy \& Society 451 at 452; Pat O’Malley, Risk, Uncertainty and Government (London: Glasshouse Press, 2004) at 132. CLHIA, "CLHIA Comments on Consultation Document on Predictivity, Genetic Testing and Insurance” (7 May 2012) at 4, online: CLHIA <http://www.clhia.ca/domino/html/clhia/clhia_lp4w_lnd_web station.nsf/page/DDE5760D748C0374852579F900508835/\$file/CE_Consult_on_Predictivity.pdf> [CLHIA, “Comments on Consultation Document”].

$4 \quad$ Neo-liberals view reliance on social security systems, as opposed to individual arrangements through the market such as private insurance, as creating a moral hazard and making people less self reliant while creating a culture of dependency. See Ericson, Barry \& Doyle, supra note 2 at 538. 
the underwriting process. There is state interest in doing so, as enhanced access to private insurance promotes the neo-liberal agenda, can justify limited or no state intervention in risk management, and can minimize reliance on the state without leaving many people destitute.

Access to insurance reflects power structures in society and is also a mechanism for constructing and reproducing social hierarchies. Tom Baker and Jonathan Simon argue that insurance technologies, institutions, and forms do not simply spread risks and compensate losses mechanistically but they "actively shape social reality." Similarly, Deborah Stone notes how certain types of insurance products such as life, accident, and sickness insurance are marketed primarily to persons of particular socio-economic backgrounds such as elites and professionals who risk losses should tragedy befall them; this legitimizes mutual responsibility and interdependence through insurance as desirable goals while denigrating dependence on social programs, principally by the poor. Dependence on means-tested social benefits is to be discouraged because it is a disincentive to productivity, self-help, and selfsufficiency. ${ }^{6}$ The financial security created and legitimized by this process helps to entrench the socio-economic advantage of the privileged and perpetuates the marginality of poorer members of society. ${ }^{7}$

One of the significant scientific breakthroughs of the twentieth century was the cracking of the human genetic code. There is a correlation between increasing availability of genetic testing and awareness of genetic risks and the future health status of individuals, families, and sometimes communities. ${ }^{8}$ Genetic testing and genetic information have become important tools in the detection, prevention, and cures of many diseases. Genetic testing has made it possible for people living with or who are susceptible to genetically-related health conditions to receive appropriate health care and to manage their conditions. Access to genetic information can also help individuals and families make informed decisions as part of managing their personal political economy based on their current and future health risks, such as reproductive and other lifestyle choices and obtaining appropriate insurance coverage to minimize the potentially disruptive effect should the risk of genetic disease materialize. ${ }^{9}$ The number of people willing to undergo predictive testing would likely increase with the discovery of a growing number of conditions believed to have genetic origins. There are also potential concerns regarding the prevalence of genetic testing and access to genetic information.

On the one hand, insurers are concerned about the potential for adverse selection and opportunism where individuals obtain insurance coverage or increase insurance amounts in light of knowledge of their susceptibility to genetic diseases without disclosing their higher

$5 \quad$ Tom Baker \& Jonathan Simon, “Toward a Sociology of Insurance and Risk” in Tom Baker \& Jonathan Simon, eds, Embracing Risk: The Changing Culture of Insurance and Responsibility (Chicago: University of Chicago Press, 2002) 27 at 32 [Baker \& Simon, Embracing Risk].

6 Deborah Stone, "Beyond Moral Hazard: Insurance as Moral Opportunity" in Baker \& Simon, Embracing Risk, ibid 52 at 57.

7 In eighteenth century England, life insurance was used not only as a form of security but also as a means of accumulating and transmitting wealth in the family. See Geoffrey Clark, "Embracing Fatality through Life Insurance in Eighteenth-Century England” in Baker \& Simon, Embracing Risk, supra note 5, 80 at 91 .

$8 \quad$ Neil A Holtzman \& Michael S Watson, eds, Promoting Safe and Effective Genetic Testing in the United States, (Bethesda, MD: National Human Genome Research Institute, 1997) online: National Human Genome Research Institute <http://www.genome. gov/10002405>.

$9 \quad$ See ibid. See also Ericson, Barry \& Doyle, supra note 2 at 551-53. 
risk status to the insurer. This constitutes a moral hazard, undermines actuarial fairness, and may be detrimental to the insurance system. ${ }^{10}$

On the other hand, there are concerns about potential genetic discrimination in access to insurance and employment opportunities, and stigmatization based on genetic information, thereby creating a genetic underclass. ${ }^{11}$ Genetic discrimination occurs when insurers make underwriting decisions based on "information obtained from genetically-based diagnostic and prognostic tests.” ${ }^{12}$ Reliance on genetic information for risk assessment is part of the practice of risk segmentation in private insurance whereby underwriting decisions are based on risk information about individuals and particular groups within the general population. This is a limited form of risk spreading that allows insurers to classify applicants for insurance into standard versus substandard risks. ${ }^{13}$ A substandard risk classification based on genetic factors means the applicant has genetic characteristics that make them susceptible to conditions that can detrimentally affect her or his health or mortality rate compared to those characterized as average in the relevant group, for example, based on age and gender. Insurers may consider the risk of illness or death as being a burden on the insurance pool that is unreasonably high relative to others in the risk pool. This may lead insurers to deny coverage altogether because the risk is considered uninsurable, to provide limited coverage and insurance amount, and to demand higher premiums with the potential of making insurance unaffordable for that individual or members of the relevant group. Risk segmentation seems justifiable from a business perspective to reduce the insurance company's exposure to risks and claims costs relative to premiums (loss ratio), and enhance their competitive edge and profitability. However, this could have other repercussions for those affected because insurance provides access to many social goods in modern society. Risk segmentation could cause a consequent detrimental impact on the ability of those affected to meaningfully participate in society, and would be contrary to socialization of risks. The question that arises is whether it is appropriate to determine a person's access to private insurance based on factors beyond the applicant's control that may not entail moral hazard, but rather result from fate because they have the misfortune of having particular genetic characteristics. ${ }^{14}$ It also gives rise to other questions, specifically regarding the accuracy and predictive value of genetic test results and the extent to which they provide a window into an individual's risk factors that affect their insurability. How different is reliance on genetic information

Tom Baker, "Insuring Morality” (2000) 29:4 Economy \& Society 559 at 569-70

See Carly Weeks, "Health insurance and 'genetic discrimination': Are rules needed,” The Globe and Mail (1 January 2012), online: The Globe and Mail <http://www.theglobeandmail.com/life/health-andfitness/health-insurance-and-genetic-discrimination-are-rules-needed/article4197442/>; "Gene map creates new frontier for discrimination,” USA Today (12 February 2001), online: USA Today <http:// www.usatoday.com/news/health/2001-02-11-genome-discrimination.htm>; Paul Recer, "Gene Map May Create Discrimination,” The Associated Press (12 February 2001), online: Yahoo News <http:// cmbi.bjmu.edu.cn/news/0102/82.htm>.

Trudo Lemmens, "Selective Justice, Genetic Discrimination, and Insurance: Should We Single Out Genes in Our Law?” (2000) 45:3 McGill LJ 347 at 355 [Lemmens, "Selective Justice”], citing Larry Gostin, "Genetic Discrimination: The Use of Genetically Based Diagnostic and Prognostic Tests by Employers and Insurers" (1991) 17:2 Am J L \& Med 109 at 110.

See CLHIA, "Comments on Consultation Document," supra note 3 at 2; Ericson, Barry \& Doyle, supra note 2 at 534 .

Risk segmentation is justified when it is based on the physical risks entailed in the subject matter of insurance and the character or attributes of the insured with the goal of promoting behavior modification to reduce moral hazards or the incentives to engineer materialization of insured risks by the beneficiary of the insurance contract. The role of insurance institutions within this paradigm is to discipline the individual. See Baker, supra note 10. 
compared to other factors that are routinely considered in making underwriting decisions such as health conditions, lifestyle, or environmental factors?

There are also questions about what constitutes genetic testing and genetic information, the legal and ethical obligations of individuals who undergo testing and health professionals, and the rights of others outside the patient-physician relationship, such as biological and social relatives to be informed of their risk status based on a relative's test results. ${ }^{15}$ As well, genetic testing may occur outside the health care context, for example in direct-to-consumer testing, without the benefit of health care professionals counselling subjects about the implications of the information obtained from testing. Nonetheless, absent regimes prohibiting insurers from relying on genetic information in determining access to and terms of insurance, the test subject has a legal duty to disclose genetic test results indicating future health risks in insurance applications to allow insurers to make accurate predictions about their risk status and hence insurability as part of the disclosure duty. ${ }^{16}$ Reliance on genetic information in insurance underwriting is allegedly justified on the basis of actuarial fairness. However, there are increasing concerns about the adverse use of genetic information, specifically about genetic discrimination in access to social goods such as insurance (life, accident and sickness, disability, health, income replacement, etc.), which have become essential in accessing basic amenities in modern society, including housing and a car, and in pursuing certain professions for individuals, families, and communities that are perceived to have unfavourable genetic characteristics. This is particularly problematic where individuals remain asymptomatic given the reality that genetic risk is often uncertain, especially in relation to conditions with multiple causal factors. At best, genetic information is no more than probabilistic regarding the materialization of the risk in question. Awareness of the potential use of genetic information in accessing social goods may discourage testing or participation in genetic research given the duty to disclose information that could affect insurability and the risk of insurers voiding insurance contracts for breach of that duty. ${ }^{17}$ The World Health Organization (WHO) has expressed concern about the danger of insurers relying on genetic information to make underwriting decisions to the detriment of individuals and groups with "unfavourable" genetic characteristics. The WHO has warned against the introduction of genetic testing without adequate safeguards to ensure test results are not used to make underwriting decisions, stating:

Genetic screening or testing should not be introduced in a country without first having clear and enforceable legislation prohibiting the use of genetic tests for health insurance or the use of genetic information by insurance companies in decisions to offer or deny health insurance, or in setting health insurance rates for

15 See Gillian Nycum, Bartha Maria Knoppers \& Denise Avard, "Intra-Familial Obligations to Communicate Genetic Risk Information: What Foundations? What Forms?” (2009) 3:1 McGill JL \& Health 21 at 26-27; Jennifer L Gold, "To Warn or Not to Warn? Genetic Information, Families, and Physician Liability” (2004) 8:1 McGill J Med 72.

16 See Insurance Act, SBC 2012, c 37, ss 51, 111; CLHIA, “Comments on Consultation Document," supra note 3 at 3; Elizabeth Adjin-Tettey, "Rethinking the Materiality Requirement for Non-Disclosure and Misrepresentation in Insurance Contracts” (2011) 89:2 Can Bar Rev 241 at 245-48.

17 See Nuffield Council on Bioethics, Pharmacogenetics Ethical Issues (London: Nuffield Council on Bioethics, 2003) at 96, online: Nuffield Council on Bioethics <http://www.nuffieldbioethics.org/sites/ default/files/Pharmacogenetics\%20Report.pdf>. 
individuals or groups. A similar ethical case can be made for not allowing use of genetic information in underwriting of disability insurance, at least for reasonable cover. ${ }^{18}$

The goal of this article is to explore the debate surrounding the use of genetic information by private insurance companies in determining eligibility or premiums. The history and purposes of life insurance are canvassed, illustrating the important role that insurance occupies in modern society and emphasizing that insurance is not a social security program. Next, this article addresses why there is a concern about genetic discrimination. Actuarial discrimination is considered reasonable and necessary. However, there could be potential harms from genetic discrimination, including the potential to create a genetic underclass. The next part in this article explores some of the questions raised in regards to genetic information, such as whether insurers should be entitled to rely on genetic information in making underwriting decisions and whether genetic information is sufficiently unique to justify arguments in favour of genetic exceptionalism. Finally, the article turns to the question of the options available to Canadian jurisdictions to deal with concerns regarding genetic information and access to insurance. Canada does not presently have any laws in this area, so the advantages and disadvantages of options that have been enacted in other jurisdictions are examined.

\section{THE History AND PURPose OF LIFE INSURANCE}

Widespread insurance, especially among the working class, was characterized as an important element in the rise of the welfare state given the focus on workers' welfare in the early nineteenth century. The insurance-based social clubs were premised on notions of social responsibility, welfare of others, and risk spreading and were founded on principles of solidarity, "friendship, brotherly love, [and] charity," ${ }^{19}$ and not the concept of risk prediction informed by the actuarial vision of insurance and an entitlement model that links benefits to contributions. ${ }^{20}$ This is part of the efforts to distinguish insurance from social security benefits or benefits generally available in the welfare state.

As a peace-of-mind contract, insurance is a mechanism for eliminating, or at least minimizing, the financial consequences of future events beyond a person's control. Insurance gives individuals some security and a means of managing the risk of misfortune by shifting the potential financial impacts of the materialization of the risk in question, either in whole or in part, to another person or risk pool. This ensures access to the resources that are necessary to deal with the consequences of uncertain future events should they befall the individual. This was part of the reason why those who initially viewed life insurance as immoral, a commodification of human life, and a "presumptuous interference with Committee on Health Research (Geneva: WHO, 2002) at 158-59, online: WHO <http://whqlibdoc. who.int/hq/2002/a74580.pdf>.

19 Nob Doran, "Risky Business: Codifying Embodied Experience in the Manchester Unity of Oddfellows" (1994) 7:2 Journal of Historical Sociology 131 at 134.

20 Tom Baker \& Jonathan Simon, "Embracing Risk" in Baker \& Simon, Embracing Risk, supra note 5, 1 at 10 . See also Doran, ibid at 133 where he notes that the notion of welfare of workers that spurred establishment of the insurance-based societies gave way to the "scientific discourse of 'risk" based on codification of the embodied experiences of workers and eventually resulted in the actuarial vision of insurance. With this model of insurance risk predictability is a significant determinant of availability of insurance coverage, rates of premiums, and level of benefits. 
Providence" 21 ultimately embraced insurance. Obtaining insurance is now a moral imperative, something that prudent people do to provide for the insured, their victims in the case of liability insurance, and for their dependents in the event of misfortune. ${ }^{22}$ Kenneth Abraham argues that although life insurance is commonly perceived as "payment to assuage grief," it is in fact compensation for future lost earning power or human capital and a form of savings. ${ }^{23}$ This may be particularly evident in life insurance for people in their prime earning years. Abraham states:

A household that purchases insurance on the life of its principal income earner is not buying protection against grief; rather it is insuring against the possibility that it will be deprived of support by the premature death of the insured. Life insurance is therefore best understood mainly as a method of compensating for income lost because of death resulting from illness or injury. ${ }^{24}$

Thus, discrimination in access to insurance may also affect access to adequate housing. ${ }^{25}$

Insurance can, therefore, be considered a mechanism for managing risks and a social good that enhances the actualization and individual well-being of the autonomous liberal subject that is in the best interests of society generally. Viewed in this light, managing risks through insurance entails a rejection of determinism, specifically the view that adversity and fortune are determined by fate. Insurance accepts misfortune as a fact of life and encourages individuals to plan towards alleviating the consequences of unfortunate events such as illness, disability, and death. As Stone notes, "[i]nsurance is one of the principal mechanisms by which modern societies define problems as amenable to human agency and collective action. It is not only an institution of repair, but also of social progress, and is a major way for communities to make life better for their individual members.”26

Private insurance is an increasing and perhaps more reliable and cost efficient source of accident compensation. For example, Abraham argues that tort reform should seriously

21 Tom Baker, "Risk, Insurance and the Social Construction of Responsibility" in Baker \& Simon, Embracing Risk, ibid at 33. See also William R Vance \& Buist M Anderson, Handbook on the Law of Insurance, 3d ed (St Paul, Minn: West Publishing, 1951) at 20-21, where the authors note that not only was life insurance considered immoral and not favourably regarded but it was also prohibited in some states.

22 The shift in attitude to accept life insurance, and ultimately other forms of insurance, reflects the social construction of risk that dissociated insurance from gambling and speculation, and characterizing the former as a mark of prudence and guarantee of family security. As well, there was a public benefit to life insurance in the eighteenth century that lent further support to its legitimization; the capital raised from premiums was invested in other commercial ventures that aided economic development in England and other parts of the British Empire. See Clark, supra note 7 at 80-81, 90-91. For a review of the evolution of the perception of insurance, particularly life insurance, first as gambling and reviled and now as responsible act of self-reliance that is to be encouraged, see Viviana A Rotman Zelizer, Morals and Markets: The Development of Life Insurance in the United States (New York: Columbia University Press, 1979); Viviana A Zelizer, Pricing the Priceless Child: The Changing Social Value of Children (New York: Basic Books, 1985); O’Malley, supra note 2.

23 This view of life insurance is consistent with the characterization of life insurance as non-indemnity contract: Kenneth S Abraham, “Twenty-First-Century Insurance and Loss Distribution in Tort Law” in M Stuart Madden, ed, Exploring Tort Law (Cambridge: Cambridge University Press, 2005) 81 at 89. Ibid.

The WHO has noted that although the ethical issues raised by discriminatory access to life insurance based on genetic information may not be as strong as those in relation to access to health and disability insurance, it also recognizes that life insurance has become essential in obtaining social goods such as housing. Thus, difficulties in obtaining life insurance due to a person's genetic characteristics can also result in discriminatory access to housing. See Advisory Committee on Health Research, supra note 18 at 159.

$26 \quad$ Stone, supra note 6 at 54. 
consider first party insurance as a source of accident compensation, among other things, because of the inefficiency of the tort system in providing compensation to accident victims. ${ }^{27}$ First party policies can provide full compensation, subject to policy limits. Making first party insurance a predominant source of accident compensation will encourage more people to purchase such policies, which could eventually reduce the cost of premiums and increase the affordability of insurance policies. This promises to be a better loss distribution mechanism than the tort system because more people can benefit from the insurance pool. ${ }^{28}$

Access to private insurance, particularly to extended health and disability insurance, is becoming increasingly important, even in countries with universal health care and other social security programs, such as Canada. Some health care services are excluded from provincial health care systems, for example dental and prescription drugs, while services such as vision care, chiropractic, and physiotherapy services are being delisted from provincial health care plans. Responsibilities for providing health care are increasingly being shifted from the public to the private sector, including the insurance market where underwriting decisions are influenced by risk factors. ${ }^{29}$ For instance, the private insurance industry in Canada provides supplementary health coverage for an increasing number of Canadians, which constitutes a significant portion of health care expenditures and provides a substantial cushioning for the publicly-funded system. ${ }^{30}$

The picture that emerges is an increasing devolution of responsibility from governments to individuals to look after their own financial security and, to some extent, their own health care needs through the private sector by obtaining insurance or by being self-insurers. This is likely to be a growing trend as governments try to eliminate their growing deficits and balance their budgets. Thus, an underwriting system that denies or limits access to private insurance due to factors such as genetic characteristics can significantly impact people's ability to respond to unfortunate events in their lives.

Notwithstanding the sense of social responsibility that underlies insurance, the actual practice of the insurance industry undermines the image of an aid institution interested in the welfare of people who experience misfortune. From the insurers' perspective, insurance is a commercial enterprise. Insurers are rational actors interested in, among other things, not assuming unreasonably high risks and maximizing profits. In fact, the early providers of life insurance in its modern form in England recognized that it was unsustainable to rely on the welfare model for providing insurance coverage and that it was important to correlate

Abraham, supra note 23 at 86-87, 99. See also Philip H Osborne, The Law of Torts, 3d ed (Toronto: Irwin Law, 2007) at 22.

Abraham, ibid at 99.

The WHO has noted that increasing privatization of health care services is a noticeable trend in many countries. See Advisory Committee on Health Research, supra note 18 at 157.

The Canadian Life and Health Insurance Industry "provides supplementary health coverage to almost 23 million Canadians, which accounts for about 12 percent of all health care expenditures in Canada." See CLHIA, "Life and Health Insurance Industry Fact Sheet: Industry Overview - A Canadian Success Story" (July 2012), online: CLHIA <http:// www.clhia.ca/domino/html/clhia/clhia_lp4w_Ind_web station.hsf/resources/Industry+Fact+ Sheet+PDF/\$file/Industry_Overview_Success_EN-pdf>;CL_HIA, "2102 Alberta Budget Submission to the Honourable Ronald Liepert, Minister of Finance, Government of Alberta" (12 December 2012), online: CLHIA <http://www.clhia.ca/domino/html/clhia/clhia_lp4w_ lnd_webstationnsfpage/AB25493245D55DFB85257964006A9E80/\$file/CLHIA_ Submission_to_Alberta_2012.pdf $>$ at 7. 
premiums to the insured's risk factors using actuarial techniques. ${ }^{31}$ A number of factors point to the business rather than welfare model of insurance institutions, including the decline in the solidarity model of insurance and the disconnect between the "sales" and "claims" visions of insurance. The business model is aimed to encourage people to take out insurance while engaging in aggressive strategies with the goal of limiting insurers' exposure to liability, for example through the use of fine prints that often escape the untrained eyes or unsuspecting customer, restrictive interpretation of contractual provisions, and liberal interpretations of exclusion clauses. ${ }^{32}$ The " "sales' vision is the promise 'to be there' and is dominated by narratives of family and the need to protect the individual against sudden misfortune. [The] 'claims' vision is a complicated amalgam of tough love and protecting the insurance fund, and it is dominated by narratives of institutional ethics and the need to protect ratepayers against fraud and abuse." ${ }^{\text {"3 }}$ The insurance industry uses the phenomenon of risk segmentation to be selective in its target audience (usually those they view to be low risk and less likely to pose moral hazards) and to insure those classified as substandard risk at higher premiums. Meanwhile, the value of insurance for most insureds is only a psychological benefit from the promised security of expectation of indemnification in the event of loss because the insured risk will not materialize for many insureds.

\section{Why IS There Concern About Genetic Discrimination?}

Private insurance is a commercial contract based on actuarial factors. Insurance pools consist of people who face common risks and premiums are based on the likelihood of the insured risk materializing. Hence, risk classification, actuarial discrimination, rate differential, and exclusion of some risks or conditions from the insurance pool are inherent in the private insurance system. High levels of risk segmentation reflect a shift from a solidaristic approach marked by socialization of risks to an individualistic model of insurance and a different conception of social responsibility with differential premiums and benefits. ${ }^{34}$ As Richard Ericson, Dean Barry, and Aaron Doyle note, "[i]nstead of social solidarity and community ... private insurance increasingly fragments populations into selective risk-rated communities with a price tag.... [T] he irony of unpooling risks has reached extreme forms in contemporary insurance markets." ${ }^{35}$ Individuals are responsible for their own risks regardless of the nature and source of that risk, thereby promoting a system of "institutionalized individualism" within the insurance system that allows individuals to manage their own risks and plan their financial security. ${ }^{36}$ The rationale is that it is unfair for

See Vance \& Anderson, supra note 21 at 21; O’Malley, supra note 2 at 120-22.

This is not to suggest that insurance companies are always successful at resisting customers' claims. In fact, based on the principle of contra preferentum, ambiguities in insurance contracts are interpreted restrictively against insurers who create these documents. Courts also have taken the position that insurance contracts should generally be interpreted liberally for the benefit of insureds. As well, courts have been very critical of unreasonable denial of claims by insurers, and consider such behaviour a breach of the duty of good faith, separate from the contractual duty to pay and capable of attracting aggravated and/or punitive damages. See Whiten v Pilot Insurance Co, 2002 SCC 18, [2002] 1 SCR 595; Fidler v Sun Life Assurance Co of Canada, 2006 SCC 30, [2006] 2 SCR 3. As well, unwillingness of insurance companies to make claims payments can also result in backlash and create public relations nightmares for insurers. See Stone, supra note 6 at 67.

Baker \& Simon, supra note 20 at 9.

See Baker, supra note 21 at 46-47. See also Ericson, Barry \& Doyle, supra note 2 at 537.

Ericson, Barry \& Doyle, ibid at 550.

Ibid at 553-54. 
persons who pose a low to moderate risk to subsidize those who pose a greater risk of loss and consequently threaten the sustainability of the insurance system. ${ }^{37}$

Actuarial discrimination is necessary to ensure fair distribution of risks within the insurance pool and also to avoid insurers assuming unreasonably high risks that could overwhelm the insurance system with a resulting frustration of the reasonable expectations of consumers. As stated by the Law Reform Commission of Canada, "[t]he very nature of private insurance legitimates discrimination." ${ }^{38}$ In fact, actuarial discrimination is considered to be reasonable and is recognized as a legitimate practice in human rights statutes through exemptions from the prohibition against discrimination on prohibited grounds provided that the discrimination is rationally connected to the provision of insurance services and consistent with industry practice. ${ }^{39}$ For instance, the British Columbia Human Rights Code states that a person does not contravene the Code by discriminating "on the basis of physical or mental disability or age, if the discrimination relates to the determination of premiums or benefits under contracts of life or health insurance." ${ }^{40}$ Similarly, the Ontario Human Rights Code states:

\footnotetext{
The right under sections 1 and 3 to equal treatment with respect to services and to contract on equal terms, without discrimination because of age, sex, marital status, family status or disability, is not infringed where a contract of automobile, life, accident or sickness or disability insurance or a contract of group insurance between an insurer and an association or person other than an employer, or a life annuity, differentiates or makes a distinction, exclusion or preference on reasonable and bona fide grounds because of age, sex, marital status, family status or disability. ${ }^{41}$
}

These provisions essentially give insurers the right to discriminate on certain otherwise prohibited grounds in making their underwriting decisions.

Insurers' right to discriminate on the basis of enumerated grounds was affirmed in Canada Life Assurance. In that case, the complainant was refused mortgage insurance due to his physical and health condition. The insurance policy at issue was offered to eligible bank customers and was not a service customarily provided to the public within the Nova Scotia Human Rights Act. While the Court found on this basis that the insurer was exempt from the legislation, several other notable comments were made. The Court found that the life insurer was entitled to assess risk based on the applicant's health and that the insurer could deny service to unreasonably high risk applicants, noting that this was not an irrelevant distinction. ${ }^{42}$ Hence, the exemption was bona fide. The Court stated:

Basic to a consideration of an application for life and disability insurance is the right of the insurer to assess the risk based in part on the state of the applicant's health. It is not irrelevant and therefore not unjust for an

See Nova Scotia (Human Rights Commission) v Canada Life Assurance Co (1992), 88 DLR (4th) 100 at 108 (NSSC) [Canada Life Assurance]; David Norwood \& John Weir, Norwood on Life Insurance in Canada, 2d ed (Toronto: Carswell, 1993) at 23-24. Bartha Maria Knoppers, Human Dignity and Genetic Heritage (Ottawa: Law Reform Commission of Canada, 1991) at 50. See also CLHIA, "Comments on Consultation Document," supra note 3 at 2-3. Zurich Insurance Co v Ontario (Human Rights Commission), [1992] 2 SCR 321 at 368. RSBC 1996, c 210, s 8(2)(b) [BC Human Rights Code]. RSO 1990, c H-19, s 22. See also BC Human Rights Code, ibid, s 8; The Saskatchewan Human Rights Code, SS 1979, c S-24.1, s 15; Human Rights Act, 2010, SNL 2010, c H-13.1, ss 9, 21. Canada Life Assurance, supra note 37 at 108-109. 
insurance company to refuse to insure at standard rates a person who fits into an above-average risk category as determined by acceptable underwriting principles. It is not discrimination to treat such a person differently than those without physical disabilities because the treating of the applicant differently is not based on an irrelevant personal difference. ${ }^{43}$

Permitting insurers to discriminate on certain grounds in their underwriting practices is not unique to Canada. The recent Equality Act 2010 in the United Kingdom permits discrimination in the insurance business provided that "(a) that thing is done by reference to information that is both relevant to the assessment of the risk to be insured and from a source on which it is reasonable to rely, and (b) it is reasonable to do that thing." 44 Permissible grounds of discrimination include disability, age, gender, sex reassignment, race, religious beliefs, and sexual orientation. Similarly, the Equal Status Act, 2000 in Ireland states that the anti-discrimination sections do not apply in relation to insurance policies where the differential treatment "(i) is effected by reference to - (I) actuarial or statistical data obtained from a source on which it is reasonable to rely, or (II) other relevant underwriting or commercial factors, and (ii) is reasonable having regard to the data or other relevant factors." ${ }^{45}$ In Australia, it is not unlawful to discriminate by refusing a life, annuity, or accident insurance policy, provided the discrimination is “(i) ... based on actuarial or statistical data on which it is reasonable for the first-mentioned person to rely; and (ii) it is reasonable having regard to the matter of the data and other relevant factors." ${ }^{46}$ Under the Disability Discrimination Act in Australia, discrimination can still be considered reasonable even where there is no actuarial or statistical data available provided that the insurer relies on any other relevant factor in making the underwriting decision. ${ }^{47}$ Similar provisions are found in the United States Americans with Disabilities Act of $1990,{ }^{48}$ and in various state statutes. ${ }^{49}$

Insurers routinely rely on family history, health status (including information about prescription drugs commonly found in patients' medical files), ${ }^{50}$ and other factors that affect insurability, such as environmental conditions, in determining risk classifications for policies that are sensitive to an insured's health status and mortality risks. It is unreasonable to preclude insurers from using genetically-related health status or health information to make underwriting decisions where the insured is symptomatic and the risk is reasonably certain. The use of predictive genetic information in making underwriting decisions is necessary to ensure a reasonably accurate risk assessment and to ensure that there is a correlation between risk classification and the terms of insurance, including the scope of coverage, premiums, insurance amount, etc. However, there are some concerns about reliance on genetic information for underwriting purposes where the predictive value of the information is low or uncertain and where it is used in relation to those who are asymptomatic. In addition to asking questions about the applicant's own health and family history, some insurers are also

Ibid [emphasis added].

(UK), c 15, Schedule III, s 21(1).

(Ireland), no 8, s 5(d).

Disability Discrimination Act 1992 (Cth), s 46(1).

Ibid, s 46(2)(g).

42 USC $\S 12101$ (2008).

See e.g. Indiana Code, title 27, art 4 § 1-4; Montana Code Annotated, title 33, § 18-206; New York Code, Insurance Law, art $42 \S 4224$.

Nuffield Council on Bioethics, supra note 17. 
asking whether family members have undergone genetic testing. ${ }^{51}$ Family history and family members testing positive for genetic diseases may put pressure on applicants to undergo testing as a pre-condition for insurance or at least to be eligible for standard rates. ${ }^{52}$ This practice can be expected to increase as genetic testing becomes widely available and inexpensive and as an increasing number of diseases are attributable, at least in part, to genetic composition. ${ }^{53}$ In fact, it may be considered unreasonable not to undergo widely available predictive tests that may reveal genetic abnormalities. Once an applicant has that information, they are required to disclose it to the insurer in an application for insurance.

Those concerned about positive results to predictive genetic testing would likely avoid or delay testing and participation in clinical research, both of which would have potential benefits for themselves and others. Individuals, families, communities, and society as a whole would be impoverished because we could lose out on the health benefits of genetic science. There is also a public health concern because avoiding or delaying testing prevents early detection, prevention, and management of genetic conditions, which creates a consequent strain on an already burdened health care system and has the potential to compromise quality of life. There does not yet appear to be widespread evidence of reluctance among the general population to undergo genetic testing for fear of potential genetic discrimination by insurers. This may partly be due to lack of common understanding of what constitutes genetic discrimination or that a positive result may affect insurability. ${ }^{54}$

There are also broader concerns about exactly what constitutes genetic information and which genetic tests can be used in the underwriting process. ${ }^{55}$ The Advisory Committee on Health Research (the Committee) has recognized the danger of widespread genetic testing and undue reliance on such information by insurers to the detriment of individuals with unfavourable genes. The Committee has noted:

As a wider range of genetic tests become available and their cost continues to decline, the incentives and abilities of insurers to use this information to discriminate against individuals with risks of developing serious disease will increase. Since genetic risks are viewed by many, even if often incorrectly, as impossible to reduce or eliminate, they may be given unduly great weight in these contexts. ${ }^{56}$

There is some evidence that concerns about genetic discrimination in access to insurance may be influencing some people to avoid or delay testing for conditions that are known to have higher mortality rates and, therefore, are likely to affect insurability. Some health care professionals and geneticists advise their patients and research subjects to obtain life insurance or other forms of insurance prior to undergoing genetic testing or participation in

David Weisbrot \& Brian Opeskin, "Insurance and Genetics: Regulating a Private Market in the Public Interest" in Michela Betta, ed, The Moral, Social, and Commercial Imperatives of Genetic Testing and Screening: The Australian Case (Dordrecht: Springer, 2006) 125 at 132.

52 See Weeks, supra note 11.

53 Weisbrot \& Opeskin, supra note 51 at 146; Tim Williams, Science and Technology Division of Parliamentary Research Branch, The Human Genome Project and its Ethical, Legal and Social Implications (Ottawa: Parliamentary Research Branch, 2000).

54 See Yann Joly, “Life Insurers’ Access to Genetic Information: A Way out of the Stalemate?” (2006) 14:3 Health L Rev 14 at 14-15.

$55 \quad$ Ibid at 15.

$56 \quad$ Advisory Committee on Health Research, supra note 18 at 157. 
research. ${ }^{57}$ For example, one third of people invited to participate in a study about the breast cancer gene refused to do so due to fear of genetic discrimination or loss of privacy. ${ }^{58}$ Medical professionals are also concerned about the potential for genetic discrimination in access to insurance. It is common knowledge among medical professionals that genetic testing could impact insurability, hence the "buy now, test later" advice. For example, this concern is recognized in the Guide to Genetic Counselling, which states:

For individuals considering presymptomatic or predictive genetic testing for hereditary conditions, particularly neurological conditions like Huntington disease, [insurability] is particularly a concern. It is generally recommended that patients make sure that they have the desired insurance coverage ([supplementary] health, life, long-term disability, long-term care) before testing. ${ }^{59}$

In fact, informing patients about the implications that genetic testing could have on their insurability may form part of the requirements for informed consent. The belief that there is genetic discrimination, regardless of what the statistics show, "accounts for the universal practice in genetic studies of including insurance discrimination as one of the potential risks to be disclosed in the informed consent process.",60

Applicants for insurance can also use genetic test results to enhance their insurability. Persons with a family history of genetic diseases such as Huntington's are known to be at risk of developing that condition even absent test results showing their susceptibility. Applicants who are aware of the consequences of their family history, the financial incentives of having a different genetic profile, and who have received negative results notwithstanding their family history would like to disclose that information to insurers to change their risk classification. A favourable risk classification can place them in the standard category or the lower end of the substandard category, with a corresponding reduction in premiums and possibly greater benefits. ${ }^{61}$

However, people should be wary about voluntary testing for underwriting purposes, especially in jurisdictions where there are no limitations on the use of genetic information. Notwithstanding optimism for negative results from testing, the reality is that some individuals will test positive for the unfavourable genes. Even if insurers cannot require genetic testing as a precondition for providing insurance, applicants who become aware of genetic information that can influence a reasonable insurer in making its underwriting

$57 \quad$ Weisbrot \& Opeskin, supra note 51 at 140.

58 Joyce Brennfleck Shannon, ed, Ethnic Diseases Sourcebook: Basic Consumer Health Information for Ethnic and Racial Minority Groups in the United States, Including General Health Indicators and Behaviors, Ethnic Diseases, Genetic Testing, the Impact of Chronic Diseases, Women's Health, Mental Issues, and Preventative Health Care Services, Along with a Glossary and a Listing of Additional Resources (Detroit: Omnigraphics, 2001) at 209.

59 Wendy R Uhlmann, “Thinking It All Through: Case Preparation and Management” in Wendy R Uhlmann, Jane L Schuette \& Beverly M Yasher, eds, A Guide to Genetic Counselling, 2d ed (Hoboken: John Wiley \& Sons, 2009) 93 at 120.

60 Mark A Hall, "Insurance and Genetic Discrimination” in Neil F Sharpe \& Ronald F Carter, eds, Genetic Testing: Care, Consent and Liability (Hoboken: Wiley-Liss, 2006) at 157.

61 Could there be potential for family discord and a source of stigmatization for persons living with disabilities or particular conditions? There could be a potential backlash from advocates for the rights of persons living with disabilities and persons with unfavourable genetic characteristics if other people, including family members, use their actual genetic profile to obtain favourable risk classification notwithstanding their family history of susceptibility to unfavourable genetic conditions. 
decision are obliged to disclose such information pursuant to the duty of utmost good faith. ${ }^{62}$ Thus, those who may submit to genetic testing in the hopes of obtaining a financial advantage out of curiosity ${ }^{63}$ or as research subjects could find themselves in a bind when they test positive for genetic abnormalities. ${ }^{64}$

Further, discrimination in access to insurance and other social goods based on genetic characteristics has the potential to create a genetic underclass or hierarchy of human beings arising from conceptions of good and bad genes and the burdens associated with the latter. There is a potential for stigmatization of those perceived to be members of a genetic underclass based on their genetic characteristics and also discriminated against in many areas of life, including denying them access to certain social goods. As David Keays states, "[t]he cascading discrimination that can result from a genetic test has the potential to foster the creation of a genetic underclass. A group of people who already have the misfortune of inheriting genetic mutations, who then suffer discrimination at the hands of insurance companies, which limits their opportunity and freedom."65 Tim Williams echoes this concern: "[O]ne of the problems some fear might result from knowledge of the human genome is the emergence of a whole population of socially marginalized individuals, unable to obtain a job, a family, insurance, or health care and stigmatized by the rest of society."66

Another concern that may arise in relation to the creation of a genetic underclass is that it would likely affect those already facing socio-economic marginalization. Access to private insurance is less likely to be an issue for those with standard employment, where these insurance products are typically available as employment benefits by way of group policies. There is generally no requirement for individual insurability for group policies. Thus, concerns about genetic discrimination and access to insurance are less likely to arise for those insured under group policies. According to the Australian Life Underwriters and Claims Association, there is less necessity for making underwriting decisions in the context of group life insurance policies because there is less likelihood of adverse selection in these circumstances given the larger pool of insureds. ${ }^{67}$

There is an apparent rise in non-standard employment as companies undergo economic restructuring and look for ways to reduce labour costs. Non-standard work includes part-time work, temporary employment, and self-employment. While some workers may choose these types of work arrangements seemingly for personal reasons, the reality of that choice may be questionable. For example, some women with young children may opt for flexible job arrangements such as part-time or self-employment so that they can have time to care for their children. Racialized people are disproportionately represented in low-paying and low-

CLHIA, "CLHIA Position Statement on Genetic Testing” (April 2010) at 1, online: CLHIA <http:// www.clhia.ca/domino/html/clhia/clhia_lp4w_lnd_webstation.nsf/resources/Guidelines/\$file/Genetic _Testing_CLHIA_Industry_Position_2010.pdf $>$.

63 Timothy Caulfield notes that genetic tests for predisposition to diseases are increasingly becoming common to the point where they can be obtained over the Internet: Timothy Caulfield, "Introduction" (2000) 45:2 McGill LJ 343 at 343.

64 See Canadian Life and Health Insurance Association, “Appendix A Reference Document: CLHIA Position Statement on Genetic Testing in CLHIA, "Comments on Consultation Document," supra note 3 [CLHIA, "Reference Document"].

$65 \quad$ Weisbrot \& Opeskin, supra note 51 at 140, citing David Keays, Submission G152, 14 April 2002.

$66 \quad$ Science and Technology Division of Parliamentary Research Branch, supra note 53 at 16.

$67 \quad$ Weisbrot \& Opeskin, supra note 51 at 127. 
status jobs and in temporary and insecure positions. ${ }^{68}$ Further, it is unlikely that many nonstandard employees will have access to extended health, accident, sickness, or life insurance as employment benefits and they are also less likely to have disposable income to purchase private insurance. Even if they are able to purchase private insurance products such as extended health, life, accident, and sickness, they will likely be done on an individual basis, which would expose such applicants to disclosure requirements that will likely entail disclosure of genetic information that might affect their insurability.

Another concern regarding the potential creation of a genetic underclass is the intersection of genetics, race, and ethnicity. Notwithstanding doubts regarding the correlation between race, ethnicity, and genetics, ${ }^{69}$ there is some agreement among geneticists that there could be a link between genetics and ancestry which, together with environmental and lifestyle factors, may point to susceptibility to certain diseases. ${ }^{70}$ Thus, certain diseases may be found mainly, but not exclusively, among people of particular descents. For example, people of African descent are known to be more likely to have sickle cell anemia, which is a chronic anemia condition with periodic episodes of pain. ${ }^{71}$ Ashkenazi Jews are more likely to be susceptible to Tay-Sachs disease, which can be either early onset or late onset, although late onset is uncommon, ${ }^{72}$ as well as Gaucher disease, which can present in early adulthood. ${ }^{73}$ Some studies have also suggested that there is a relative excess of autosomal recessive disorders among Arab populations, which is attributed to the high rate of consanguinity among some Arab populations. ${ }^{74}$ Therefore, there is a concern that genetic discrimination regarding access to insurance could exacerbate racial and ethnic discrimination faced by some minority groups. The US Congress has recognized the concern about genetic discrimination partly because of the treatment of African-Americans in the 1970s with the massive sickle cell screenings and the resulting exclusion of many people of AfricanAmerican descent from certain occupations, stating in the Genetic Informtion NonDiscrimination Act of 2008:

Although genes are facially neutral markers, many genetic conditions and disorders are associated with
particular racial and ethnic groups and gender. Because some genetic traits are most prevalent in particular
groups, members of a particular group may be stigmatized or discriminated against as a result of that genetic
information. This form of discrimination was evident in the 1970s, which saw the advent of programs to
screen and identify carriers of sickle cell anemia, a disease which afflicts African-Americans. Once again,
State legislatures began to enact discriminatory laws in the area, and in the early 1970s began mandating
genetic screening of all African Americans for sickle cell anemia, leading to discrimination and unnecessary

Colour of Justice Network, “The Colour of Poverty,” online: Colour of Poverty <http://www.colourof poverty.ca/>. See also Judy Fudge \& Rosemary Owens, eds, Precarious Work, Women, and the New Economy: The Challenge to Legal Norms (Portland: Hart, 2006) at 12-13; Cynthia J Cranford, Leah F Vosko \& Nancy Zukewich, “The Gender of Precarious Employment in Canada” (2003) 58:3 Relations Industrielles/Industrial Relations 454; Robert D Wilton, "Working at the Margins: Disabled People and the Growth of Precarious Employment” in Dianne Pothier \& Richard Devlin, eds, Critical Disability Theory: Essays in Philosophy, Politics, Policy, and Law (Vancouver: UBC Press, 2005) 129. This is in contrast to the common portrayal in mainstream media that there are links between ethnicity and health issues, specifically that heritage affects health risks.

Nuffield Council on Bioethics, supra note 17 at 53-54.

Shannon, supra note 58 at 125-26.

Ibid at 135, 137; Gold, supra note 15 at 73.

Shannon, ibid at 101.

Samia A Temtamy, Mona S Aglan \& Nagwa A Meguid, “Genetic Disorders in Egypt” in Ahmad S Teebi, ed, Genetic Disorders Among Arab Populations, 2d ed (Heidelberg: Springer-Verlag, 2010) 219 at 223; Hanan Ali Hamamy, "Genetic Diseases in Iraq" in Teebi, ibid, 297 at 300. 
fear. To alleviate some of this stigma, Congress in 1972 passed the National Sickle Cell Anemia Control Act, which withholds Federal funding from States unless sickle cell testing is voluntary. ${ }^{75}$

There may also be a concern that if genetic discrimination could lead to a genetic underclass, there may be a tendency for some individuals to undergo pre-natal screening to avoid having children with what are perceived as unfavourable genetic characteristics and to engage in the practice of genetic engineering. Testing may alleviate parents' anxiety about the child's genetic health and assist them in making decisions about whether to carry the fetus to full term or not. ${ }^{76}$ However, this may also contribute to concerns relating to the practice of eugenics. There is a concern that "[g]overnments may inadvertently legitimize the practice of eugenics by forcing choices on individuals for the sake of economy and efficiency."77 Parents may fear that their children might face similar genetic discrimination and may seek to prevent that by terminating pregnancies where there is a reasonable chance of a child being born with genetic abnormalities. ${ }^{78}$ These concerns were illustrated in the film Gattaca, which portrays the concept that "desirable” human features can be engineered through scientific manipulations of genes. ${ }^{79}$ In that film, the older child's genetic profile was identified at birth and showed the odds of him experiencing certain diseases including heart attack, and his probable intelligence level, mortality rate, etc. The parents were denied insurance coverage because of the son's genetic characteristics. The older child felt like a member of a genetic underclass and questioned his parents about why they did not entrust their fate in geneticists, given that science has an answer for nature's imperfections. The parents, feeling the weight of having a child with genetic deficiencies who has been told that he could never reach his ambition because of limitations arising from his genetic make-up, had their second child genetically engineered to screen out unfavourable characteristics. The approach taken in Gattaca is illustrated in the following quote by Vincent, the main character: "Consider God's handwork; who can straighten what he hath made crooked?" 80

While Gattaca is fictional and the portrayal of concerns about the potential for genetic discrimination may be extreme, it nevertheless provides an insight into how individuals who are perceived to have unfavourable genetic characteristics may participate in society. Genetic discrimination could have the potential to create a genetic underclass that may experience discrimination in access to social goods such as insurance and employment, and may also be stigmatized. It also appears to provide a solution to preventing individuals from being relegated to a genetic underclass by pointing to the promise of science to make genetically "perfect" human beings. However, the film appears to ignore the social and ethical implications of genetic engineering or phenomena such as pre-natal testing to screen out

Pub L No 110-233, § 2(3), HR 493.

See Gold, supra note 15 at 73.

Ontario, Information and Privacy Commissioner, Submission to the Ontario Law Reform Commission: Report on Genetic Testing (Toronto: Information and Privacy Commissioner, 1992) at 2, online: Information and Privacy Commissioner of Ontario <http://www.ipc.on.ca/images/Resources/upgentest.pdf $>$.

Some perceive genetic engineering as an advancement in science that should be taken advantage of to create superior human beings: "I not only think we will tamper with Mother Nature, I think Mother Nature wants us to.” Dr. Willard Gaylin, Clinical Professor of Psychiatry at Columbia College of Physicians and Surgeons, quoted in Gattaca, 1997, (Culver City, Cal: Sony Pictures Entertainment). This film centered on the concept that good human features can be engineered through scientific manipulation of genes.

Gattaca, ibid.

Ibid. 
children likely to be born with genetic abnormalities. In fact, in the film, reliance on science to prevent procreation of genetically flawed offspring is perceived as a responsible thing to do and parents who do not undergo such testing or take positive steps to alter their children's genetic characteristics may potentially be perceived as unreasonable or as "bad parents" and may be blamed for having children who belong to a genetic underclass. Further, reliance on science to screen out children who are likely to be born with genetically-related diseases entails an element of blind faith in science. To what extent can science determine a person's genetic code for predictive purposes including diseases, life expectancy, and mortality? Progress in genetic science coupled with widespread genetic testing for non-therapeutic purposes may provide an opportunity to peek into an individual's entire genetic profile and could raise concerns about the unauthorized use of genetic materials as well as about genetic discrimination.

\section{GENETIC INFORMATION}

\section{A. SHOULD INSURERS BE ENTITLED TO RELY ON GENETIC INFORMATION IN MAKING UNDERWRITING DECISIONS?}

The current Canadian approach is self-regulation by the CLHIA, which states that its members should not demand testing as a condition for insurance ${ }^{81}$ However, individuals who have already undergone genetic testing prior to their application for insurance have a duty to disclose test results. The CLHIA has also stated that insurers cannot ignore test results in making their underwriting decisions. ${ }^{82}$ This means that while testing cannot specifically be mandated for insurance purposes, once a person is aware of a genetic condition that can affect their health or mortality they have a duty to disclose such information in applications for accident, sickness, and life insurance. Failure to disclose constitutes a breach of the disclosure duty, resulting in the policy being voided even if loss arises from a condition causally unrelated to the genetic condition at issue. ${ }^{83}$ This voiding would be subject to the incontestability principle for policies that have been in existence for two years or more, which applies absent fraud on the part of the insured. ${ }^{84}$

The CLHIA seems to provide some protection for applicants' genetic information where they have not already undergone genetic testing. However, the effectiveness of this protection is questionable. In reality, reliance on family history in making underwriting decisions could have the same effect as access to genetic information where there is a correlation between family history and the chances of suffering from particular geneticallyrelated conditions. Insurers may be reluctant to provide coverage or classify individuals as substandard risks based on family history and the likelihood of individuals inheriting those genetic conditions even absent test results showing susceptibility to genetically-related health

CLHIA, “Comments on Consultation Document,” supra note 3 at 4.

Ibid.

See Henwood v Prudential Insurance Co of America, [1967] SCR 720; Walsh v Unum Provident, 2012 NSSC 86, 314 NSR (2d) 154; Fernandes v RBC Life Insurance Co, 2009 ONCA 864, 99 OR (3d) 628; Thompson v Maritime Life Assurance Co, 2003 MBQB 229, [2004] 9 WWR 153; Jones Estate v CUMIS Life Insurance Co, 2003 MBQB 5, 171 Man R (2d) 123.

See Insurance Act, supra note 16, ss 51-52 (Life), 111-13 (Accident and Sickness); Insurance Act, RSO 1990, c I.8, ss 183-84 (Life), 308-10 (Accident and Sickness); Insurance Act, RSA 2000, c I-3, ss 652-53 (Life), 719-21 (Accident and Sickness); Insurance Act, RSNS 1989, c 231, ss 82-84 (Accident and Sickness), 185-86 (Life). 
conditions. As the Nuffield Council on Bioethics points out, the same probabilistic information obtained from a genetic test about a person's susceptibility to a disease may also be possible to obtain by scrutinizing their family history. ${ }^{85}$ For instance, where a person has a family history of Huntington's disease there is a high probability that they will inherit the genes responsible for the condition. Although insurers cannot directly demand genetic testing to determine an individual's susceptibility, applicants may feel compelled to do so where there is a likelihood they may be susceptible to an unfavourable genetic condition based on their family history. This concern is illustrated in the case of Brynne Stainsby, an Ontario woman with a family history of Huntington's disease who felt compelled to undergo testing due to difficulties in obtaining insurance to start a chiropractic practice. Although Stainsby did not want to undergo testing because, among other things, she did not want to know of her susceptibility for the disease, she felt that it was necessary to do so, as she needed the insurance coverage for her professional practice. ${ }^{86}$ The current regime of self-regulation by the insurance industry does not adequately protect consumers, given the duty to disclose test results that could affect insurability and the reliance on family history. Some government regulation is necessary to protect consumers.

\section{B. The Predictive VAlue Of Genetic Information: CONCERNS REGARDING RELIANCE ON GENETIC DATA}

Concerns about the creation of a genetic underclass subject to discrimination including access to insurance and stigmatization cannot be ignored. There are also concerns about how insurers use genetic information in making underwriting decisions. Where an applicant is asymptomatic but has tested positive for a genetic disorder, insurers will consider the chances of that condition manifesting in determining the applicant's risk status. This leads one to question the predictive value of the test results and the accuracy of insurers' interpretation of genetic data. Historically, these concerns have been illustrated in the case of sickle cell anemia. As Jon Backwith and Lisa Geller state, "if we look at this history retrospectively, African Americans were the canaries in the mine, exhibiting at an early point in genetic research the potential dangers of genetic information." ${ }^{87}$ The discrimination and stigmatization in the case of sickle cell anemia was largely a result of misinformation about carrier status versus those actually suffering from the condition, thereby highlighting concerns about the predictive value of testing and insurers' use of test results to make underwriting decisions.

There are a number of concerns with the current regime of self-regulation by the insurance industry regarding the use of genetic test results in insurance underwriting. For instance, individuals may choose to remain ignorant about their genetic characteristics and health risks by delaying testing to avoid having to disclose unfavourable genetic information for fear of

85 See Nuffield Council on Bioethics, supra note 17 at 6.

86 Weeks, supra note 11. See also Theresa Boyle, "Young woman faces insurance hoops due to father with Huntington's” (18 May 2011), online: Health Zone <http://www.healthzone.ca/health/newsfeatures/ article/992995--young-woman-faces-insurance-hoops-due-to-father-with-huntington-s?bn=1>. Here, another Ontario woman felt compelled to undergo testing in order to obtain insurance necessary to practice as a chiropractor. She decided she was not ready to learn her test results and managed to obtain insurance sufficient to allow her to practice.

87 Jon Beckwith \& Lisa Geller, "Genetic Discrimination: Anticipating the Consequences of Scientific Discovery” in Sharpe \& Carter, supra note 60 at 146. 
genetic discrimination, either through denial of insurance or by being classified as a substandard risk and, therefore, being charged higher premiums. ${ }^{88}$ In some cases, health care professionals may counsel their patients to seek life insurance or other forms of insurance prior to genetic testing. ${ }^{89}$ The concern that the use of genetic information by the insurance industry will discourage people from undergoing genetic testing for therapeutic or health related reasons was recognized in the Concordat and Moratorium on Genetics and Insurance in the United Kingdom. ${ }^{90}$ The Concordat states that " $\left.\mathrm{t}\right]$ here remain concerns that a minority of patients might be deterred from taking predictive genetic tests, if they fear that insurance companies may discriminate against them unfairly on the basis of the test results. The Concordat addresses those fears." ${ }^{11}$ In addition to concerns about obtaining individual insurance, those who have considered genetic testing have also mentioned concerns that it may prevent people from reaching out to support groups, that while they may have group insurance now, they may experience problems if they ever have to purchase individual insurance in the future, and concerns regarding how to avoid discrimination and labelling of their children or family. ${ }^{92}$ Delay in or refusal to undergo testing could have personal and societal implications, including delaying or precluding adoption of preventative measures and postponing counselling, treatment, or general managing of one's genetically-related health risks. This could jeopardize their health and well-being, as well as result in higher health care costs.

In addition to the potential for individual health effects resulting from the postponement or refusal to undergo testing and treatment to gain access to insurance, there may also be more widespread social and public health effects. Not only is there the concern that the individual will delay treatment for their disorder, but there are broader health concerns because a lack of participants in genetic testing may result in a potential setback in genetic research, diagnosis, and treatment of genetically-related diseases. This could create an increased burden on the health care system and could potentially compromise the quality of life of the individual. If people are reluctant to undergo genetic testing due to fear that they will suffer genetic discrimination by insurers, they may also be reluctant to participate in genetic research out of fear of subsequent discrimination if the test results obtained in the study were positive. These concerns were found to be present in a breast cancer study concerning insurability. ${ }^{93}$ Therefore, if the insurance industry were to have access to genetic tests, not only could this have health implications for the participants but this could also affect genetic research, specifically the ability to recruit research subjects. ${ }^{94}$

An applicant for insurance is only obliged to disclose material facts within their actual or constructive knowledge and the obligation does not include information they have no way of knowing, for example what genetic tests might reveal about their health risk if there was nothing to indicate their susceptibility to particular health risks.

89 See the discussion of "buy now, test later" at supra notes 57-60 and accompanying text.

90 HM Government \& Association of British Insurers, Concordat and Moratorium on Genetics and Insurance (London: Department of Health, 2005) online: Department of Health <http:// www.dh.gov.uk/pord_consum_dh/groups/dh_digitalassets/@dh/@en/documents/digitalasset/dh_410 6050.pdf [Concordat].

$91 \quad$ Ibid, $\mathrm{s} 4$.

92 Doris Teichler Zallen, To Test or Not to Test: A Guide to Genetic Screening and Risk (New Brunswick, NJ: Rutgers University Press, 2008) at 102-103.

Lemmens, "Selective Justice," supra note 12 at 364.

Ibid at 365 . 


\section{GENETIC EXCEPTIONALISM: IS GENETIC INFORMATION SUFFICIENTLY UNIQUE TO WARRANT DIFFERENT TREATMENT?}

As previously discussed, actuarial discrimination is necessary for effective underwriting. Thus, one may question the alleged uniqueness of genetic test results in regards to their use in making underwriting decisions. ${ }^{95}$ As Mark Rothstein states, "[o]ne of the most important and contentious policy issues surrounding genetics is whether genetic information should be treated separately from other health information." 96 Specifically, is genetic information sufficiently unique compared to other health-related data and family history that is routinely relied on by the insurance industry to justify differential treatment of genetic information? ${ }^{97}$ According to a 2001 survey, 90 percent of respondents stated that they either strongly agree or agree that genetic information is different from other forms of medical information and that stricter rules are required to govern access to genetic information compared to other forms of personal information. ${ }^{98}$ Is genetic information truly qualitatively different or unique compared to other forms of heath information that insurers routinely rely on to make underwriting decisions to justify differential treatment of genetic information? In other words, is genetic exceptionalism justified in access to insurance?

\section{InSURERs’ ARgUMENTS AGAINST GENETIC EXCEPTIONALISM}

Insurers argue that genetic information is not unique and that it is no different from other information, such as health status, disability, and family history, that is already relied on in making underwriting decisions. Furthermore, insurers have always relied on health factors including genetic information, whether from family history or genetic testing, to make underwriting decisions in relation to policies that require assessment of applicants' mortality risks. In fact, family history for some single gene conditions such as Huntington's disease are already being used by the insurance industry, regardless of whether applicants have undergone genetic testing or not. This has the effect of reducing the potential impact of testing. ${ }^{99}$ Insurers have raised several arguments supporting their position against genetic exceptionalism.

One argument against the notion of genetic exceptionalism is that to ignore genetic information would lead to potential discrimination among policyholders with susceptibilities to other conditions relied on in underwriting decisions. Trudo Lemmens states that "statutes singling out genetic susceptibility as a category, and offering it much wider protection than other similar health conditions, although intended to promote equity in access to social goods, may themselves be ineffective and to some extent even inequitable.”100 The concerns

Timothy Caulfield \& Nola M Ries, “Consent, Privacy and Confidentiality in Longitudinal, Population Health Research: The Canadian Legal Context” (2004) 12 Health LJ 1 (Supplement) at para 22. Mark A Rothstein, “Genetic Exceptionalism \& Legislative Pragmatism” (2005) 35:4 The Hastings Center Report 27 at 27.

See Lemmens, “Selective Justice,” supra note 12 at 369-72; CLHIA, “Reference Document,” supra note 64.

Caulfield \& Ries, supra note 95 at para 22.

Diego F Ossa \& Adrian Towse, "Genetic Screening, Health Care and the Insurance Industry: Should Genetic Information be Made Available to Insurers?” (2004) 5:2 European Journal of Health Economics 116 at 117; Trudo Lemmens, Daryl Pullman \& Rebecca Rodal, Genome Canada Policy Brief no 2, Revisiting Genetic Discrimination Issues in 2010: Policy Options for Canada (15 June 2010 ) at 3. Lemmens, "Selective Justice," supra note 12 at 349. 
that are raised in the context of genetic testing are equally present in relation to other forms of medical testing, such as high cholesterol or family history. ${ }^{101}$ As Lemmens argues, it is "difficult to convincingly demarcate genetic information from other health-related information." 102 Rather, privacy issues exist regardless of the type of medical information being requested. Therefore, it may be most appropriate to deal with protection concerns for all sensitive medical data and not just genetic information. ${ }^{103}$ Furthermore, Lemmens argues that statutes that are based on genetic exceptionalism have the effect of "[treating] people who are similarly situated differently." 104 As stated by Zimmern, “[a] society which supports institutions and structures which adversely affect people with genetic disease more than those with disease that is not primarily genetic in origin is clearly undesirable and should be discouraged.”105

Another argument against genetic exceptionalism relates to actuarial equity. This argument is ethical, and it states that it is not fair or equitable to policyholders to charge people that have the same risk different rates. The insurance industry argues that it would be unfair to make low-risk insureds subsidize individuals who are at a higher risk. ${ }^{106}$ Insurers argue that risk segmentation on the basis of genetic conditions is necessary to discriminate and to exclude some people from the insurance pool in order to ensure fairness to policyholders. ${ }^{107}$

Perhaps one of the largest concerns raised by insurers is over the financial viability of the insurance industry. The purpose of insurance is the pooling of risks among persons who face similar risks. However, an essential characteristic of insurance is that the materialization of risks, and hence the insureds' losses, must be fortuitous or random. The law of large numbers that enables the risk to be spread widely ensures the viability of the system by creating what has been referred to as "moral opportunity" and the chance to combine financial forces with persons who face similar risks, and together help those for whom that risk materializes. ${ }^{108}$ This transforms what looks like bilateral contracts between individual policyholders and insurers into social and collective enterprises for spreading the responsibility associated with the materialization of the common risk for individuals within the pool with a resulting socialization of those risks. ${ }^{109}$ Although all members of the pool face a common risk, the risk will materialize only for a small number of persons in the pool. It remains uncertain who will actually suffer losses and when; losses must be unexpected. The likelihood that a person will actually suffer the loss in question means the loss ceases to be unexpected. There is concern that persons with knowledge of their susceptibility to certain genetically-related conditions and mortality risks will obtain insurance for larger amounts, thereby resulting in adverse

Ibid at 370 .

Ibid at 377 .

Ibid at 366. See also Lawrence O Gostin \& James G Hodge, Jr, "Genetic Privacy and the Law: An End to Genetics Exceptionalism” (1999) 40:1 Jurismetrics 21 at 41, 53 (American context; that geneticsprivacy statutues have failed to recognize how genetic information is "part of a seamless continuum of health information"). See generally Rothstein, supra note 96.

Lemmens, "Selective Justice," ibid at 380. See also Gostin \& Hodge, Jr, ibid at 33.

RL Zimmern, "Genetic Testing: A Conceptual Exploration” (1999) 25:2 Journal of Medical Ethics 151 at 153.

William Nowlan, “A Rational View of Insurance and Genetic Discrimination,” (2002) 297:5579 Science 195 at 195.

Lemmens, "Selective Justice," supra note 12 at 383-84.

Stone, supra note 6 at 53-54.

Baker, supra note 21 at 36-38; Stone, ibid at 55. 
selection. This would undermine the purpose of insurance because the loss will not be unexpected. Also, other members of the pool will be made to unfairly subsidize high-risk members of the pool, thereby resulting in an unacceptable level of socialization of the risk. Insurers seek to avoid such an outcome by requiring that applicants for insurance disclose all information within their knowledge that will likely influence a reasonable insurer in making underwriting decisions to promote effective risk segmentation. Insurers must decide whether the applicant for insurance is to be classified as standard (no difficulty getting insurance), substandard (could be insured, but at higher rates of premiums than average rates - pre-existing conditions are often excluded from coverage or not covered for the initial life of the insurance contract), or uninsurable (too costly to provide coverage). ${ }^{110}$

Further, the potential for adverse selection from not using genetic information in insurers' underwriting decisions undermines the risk pooling objective of insurance as well as the rationale for the disclosure duty. Inequality in knowledge between an insured and insurer regarding the insured's risks arising from genetic factors gives the insured an unfair advantage and prevents insurers from accurately predicting an applicant's risk factors. ${ }^{111}$ These are based on wider arguments that information asymmetry can disrupt the free marketplace and lead to adverse effects on the insurance industry. ${ }^{112}$ There is also an economic efficiency argument against genetic exceptionalism and the potential for adverse selection. Not only are people who find out that they are susceptible to a genetic disease likely to obtain insurance or do so in higher amounts, but those people who get negative results may be more likely to opt out of insurance altogether on the basis that they would then no longer have a need for life insurance. ${ }^{113}$ This would have the effect of having a disproportionate amount of high-risk insureds in the insurance pool, which would have the potential to destabilize the insurance industry and threaten the commercial viability of the industry.

\section{ARGUMENTS FOR GENETIC EXCEPTIONALISM}

Despite agreements among insurers that genetic information is not sufficiently unique and that a prohibition of the use of genetic information would impact actuarial fairness and the viability of the insurance industry, the public perception is to generally regard genetic information as being unique. This position enjoys support within the scientific community that views genetic information as being sufficiently different from other medical information including information obtained from clinical tests. There are several reasons given for this uniqueness. Information obtained from genetic testing has implications, not just for the individual, but also for their family and sometimes for their communities, while other medical information may only pertain to an individual, such as blood sugar level. The same

110 See Trudo Lemmens, "Genetics and Insurance Discrimination: Comparative Legislative, Regulatory and Policy Developments and Canadian Options” (2003) Health LJ (Special Edition) 41 at 49 [Lemmens, "Genetics and Insurance Discrimination”].

111 Lawrence Low, Suzanne King \& Tom Wilkie, “Genetic Discrimination in Life Insurance: Empirical Evidence from a Cross Sectional Survey of Genetic Support Groups in the United Kingdom” (1998) 317:7173 Brit Med J 1632.

112 Nowlan, supra note 106 at 195. In Carter v Boehm (1766), 97 ER 1162 at 1164 (KB), Lord Mansfield emphasized the importance of symmetry of information about the risk to be insured between the insured and insurer as necessary for a proper risk assessment.

113 Weisbrot \& Opeskin, supra note 51 at 141, citing Australian Prudential Regulation Authority, Submission G279, 31 December 2002. 
information about susceptibility may be obtained from other sources such as family history. However, that information may be individualized to particular families and not lend itself to generalizations about a group's possible genetic information.

Genetic information may have further implications for reproduction and characteristics of future generations. Genetic test results may be predictive of present and future conditions of the individual test subject, as well as others related to that person. There could be room for further findings to be derived from genetic data beyond the purpose of testing or state of knowledge at the time of testing. There are also concerns that there may be stigma associated with genetic test results which could lead to genetic discrimination and some form of eugenics as some people may take steps to avoid having children with susceptibility for genetic diseases. Support for genetic exceptionalism is found in current medical practice that has "special" categories of medical information where special protections have been adopted, such as HIV/AIDS and mental illness. Furthermore, it is part of the political reality that there is greater support for genetic non-discrimination than for more general laws relating to all health information. ${ }^{114}$ In addition, there may also be concerns relating to genetic prophecy, generalization to families, race, ethnicity, and communities, and the fact that one has no control over one's genome. ${ }^{115}$

One of the larger issues relating to arguments supporting genetic exceptionalism is about privacy concerns, such as the right to remain ignorant of one's genetic status that can affect their health or mortality. However, ignorance may be increasingly difficult to sustain as genetic testing for a variety of purposes becomes widely available and inexpensive. Not undergoing genetic testing that is widely accessible may give rise to negative inferences about a person's susceptibility to a particular genetic condition, especially in the face of evidence such as family history or identity markers like racial/ethnic background and place of origin that may make it difficult for individuals to obtain insurance. An example of this is the recent experience of Katie Lingard, an Ontario woman who was refused coverage due to a family history of Huntington's disease and was "compelled" to undergo testing, essentially taking away her autonomy and right to choose not to know of her susceptibility to a genetic disease (Huntington's disease) that had already afflicted her father. Since insurance was essential for the chiropractic business that she was seeking to enter into, she essentially had no choice but to undergo genetic testing. ${ }^{116}$

Rothstein, supra note 96 at 30.

Lemmens, "Selective Justice," supra note 12 at 370; Nycum, Knoppers \& Avard, supra note 15 at 21; Gold, supra note 15 at 73.

Boyle, supra note 86. Another (older) example, where the person in question was not ready to undergo testing, was Heather Westendorp, whose children were refused life insurance due to a family history of Huntington's (where it was a great-grandmother who had the disease). She did take the test several months after her father was diagnosed (Shelley Page, "Genetics breeds new bias," The Ottawa Citizen (28 March 1995) B1). Some of the other privacy concerns that arise in the context of genetic information and insurance include the right not to have one's genetic information collected, the right not to have one's genetic information used for unauthorized purposes, the right not to have one's genetic information disclosed to a third party, etc. See Ontario, Information and Privacy Commissioner, supra note 77 at 3 . 


\section{SUMMARY}

Reliance on genetic information to determine access to social goods undoubtedly has repercussions beyond the individual test subject and the purpose of testing. Nevertheless, the question still remains whether differences between genetic information and other health information warrant differential treatment including non-reliance on the former in determining insurability. Although some legislative regimes, policymakers, and health professional bodies perceive genetic information as possessing special characteristics as compared to other medical information, there is also support for viewing genetic information in the same way as other medical information and according it the same level of confidentiality protections as other sensitive health information. ${ }^{117}$ For example, the Manitoba Personal Health Information Act defines "personal health information" to mean information about particular individuals relating to the person's "health, or health care history, including genetic information." ${ }^{118}$ Other regimes recognize the special status of genetic information and accords it a different level of protection compared to other health information. ${ }^{119}$ However, it is questionable whether all genetic information should be accorded the same special status. ${ }^{120}$ As well, even if genetic information deserves to be treated differently than other medical information, it can be argued that the differential status is appropriate in relation to the confidentiality and disclosure obligations of the data subject and of health professionals but that it makes no difference to using that information for determining insurability. Insurers have an obligation to treat all personal information as being confidential. Among other things, the distinction between genetic and medical information is increasingly becoming difficult to justify as scientists discover a growing number of diseases with genetic origins. The concern has been expressed that according genetic information special status as compared to other health information risks reinforcing notions of genetic reductionism. ${ }^{121}$ It also diverts attention away from risk factors other than genetic characteristics affecting one's health that also inform insurability, such as environmental and lifestyle. ${ }^{122}$ The alleged uniqueness of genetic information as compared to other medical information and family history appear to be based on public perceptions, fuelled by the media to some extent, and not necessarily backed by science. ${ }^{123}$

\section{The MaXimum Utility ARgument}

While prohibiting insurers from using genetic test results in their underwriting decisions may cause some adverse selection, it may also increase overall social welfare. ${ }^{124}$ The potential risks of insurers being blindsided to assume unreasonable risks arising from adverse selection must be juxtaposed with the overall societal benefits from genetic testing. Allowing insurers to use genetic test results in their underwriting practices could result in broader social costs. As already stated, there is concern that people may not get tested out of fear of

See Gold, supra note 15 at 77; Nycum, Knoppers \& Avard, supra note 15 at 26-29, 35; Nuffield Council on Bioethics, supra note 17 at 5.33 .

CCSM, c P33.5, s 1(1).

Nucum, Knoppers \& Avard, supra note 15 at 27-30.

See Nuffield Council on Bioethics, supra note 17.

Gold, supra note 15 at 77; Science and Technology Division, supra note 53.

Gold, ibid.

Nuffield Council on Bioethics, supra note 17 at 1.12-1.14.

Mattias K Polborn, Micheal Hoy \& Asha Sadanand, “Advantageous Effects of Regulatory Adverse Selection in the Life Insurance Market” (2006) 116:508 The Economic Journal 327 at 328. 
being denied insurance should they test positive to a genetic condition that affects their health and mortality rates. This could undermine the opportunity for better diagnosis and timely interventions and/or treatment of genetic diseases that could improve the quality of life for persons living with those conditions and could potentially minimize the need for health care. This cost to the health care system outweighs the benefits of increased premiums and lower insurance amounts to insurers. ${ }^{125}$ Optimal public policy on genetic testing must reflect overall societal benefits, while also taking into account the trade-offs of increased premiums and the overall cost to society through increases in health care costs and adverse impacts to the health of individuals. ${ }^{126}$ Insurance companies argue that adverse selection resulting from this denial would lead to an increase in premiums for everyone, since they could not discriminate only against those who were at an increased risk, and that there would be an overall decline in consumer welfare. ${ }^{127}$ However, the potential increase in premiums must be contrasted with the detrimental health effects resulting from people not undergoing testing for fear of being classified by insurers as substandard risk and, hence, being subject to higher premiums or of being denied coverage. ${ }^{128}$

Given the ubiquitous nature of insurance in modern society, a system that promotes access to insurance enhances financial security for many people, maximizes overall societal welfare, and improves quality of life. This benefit for the greater public good is a form of socialization of risks and outweighs concerns about adverse selection. Eliminating concerns about the use of genetic data in insurance underwriting would not necessarily encourage testing; concerns about stigmatization in other areas such as employment remain. Arguably there could be protection for persons who face such discrimination under human rights legislation.

\section{E. QUESTIONS That SHOULD INFLUENCE RESPONSES TO CONCERNS ABOUT THE USE OF GENETIC DATA}

There are two main questions that address the debate between the use of genetic information and insurance: (1) would there be an increase in premiums if insurers were allowed to use genetic information of applicants to underwrite insurance premiums, and (2) what additional costs would result from adverse selection if insurers were not allowed to use genetic information in underwriting? ${ }^{129}$ If insurers were allowed to use genetic information but there was no corresponding increase in premiums, then there would seem to be little concern about the use of genetic information. Furthermore, if insurers were not able to use genetic information but they did not experience additional costs from adverse selection, then there would be little justification for giving insurers access to genetic information. It is only if this information would result in increased costs for insurers and other policyholders through higher premiums that access to genetic information would need to be granted. The potential for adverse selection raises concerns about actuarial fairness; if insurers did not have access to genetic information and adverse selection were to result, there would be an increase in premiums across the entire pool of insureds.

Ibid.

Ibid.

129 DJ Balding, M Bishop \& C Cannings, eds, Handbook of Statistical Genetics, 3d ed, vol 2 (Chichester: John Wiley \& Sons, 2007) at 1352.
} 
Arguments relating to adverse selection resulting from a restriction on the use of genetic testing may not necessarily correlate with the evidence, although given that genetic science is still evolving, this may change as information becomes more widespread. Any adverse selection is likely to be insignificant at present, as insurers still have access to family history. ${ }^{130}$ In a study of the BRCA $1 / 2$ Gene (the breast cancer gene), a simulation found that there would only be "modest adverse selection costs" associated with a ban on genetic information in the insurance industry. ${ }^{131}$ While this study recognizes the possibility for adverse risk selection, which can occur where applicants have access to private information that insurers do not, and that this can drive up the price of insurance and generate adverse selection costs, the study found the effect in the short- to medium-term would be minimal. ${ }^{132}$ The researchers attributed this in part to the fact that the cost of the test is still quite high and is unlikely to decline anytime soon, as the test is still patented. ${ }^{133}$

It is important to note that concerns over discrimination and access to insurance are not exclusive to genetic disorders. Many of the issues seen in the context of genetic information and insurance have also been seen in the context of HIV/AIDS from the late 1980s onward. In fact, the term genetic exceptionalism was derived from the HIV exceptionalism theories that existed prior to issues about genetic testing. ${ }^{134}$ Many of the same fears of people who are considering genetic testing now were present for those considering HIV testing previously. There were concerns that a positive test result could lead to denial of insurance, which in turn could affect employment, credit, and mortgages. There were also concerns that fears about discrimination could prevent or interfere with open communication with physicians, which would adversely affect people's health. ${ }^{135}$ Arguments relating to actuarial fairness and adverse selection were also made by insurers in the context of HIV testing and many insureds argued for an HIV exception based on the uniqueness of HIV and AIDS in comparison to other forms of medical information. In the context of HIV and insurance underwriting, insurers argued that it would be actuarially unfair to low-risk insureds not to exclude highrisk insureds from insurance pools, such as those at risk of contracting HIV. This concept of actuarial fairness expresses a "moral judgment that fair underwriting practices must reflect the division of people according to the actuarially accurate determination of their risks."136 Essentially, insurers were arguing that it would be unfair if they were to fail to deny coverage or if they were to require equal premiums for high-risk insureds, namely those at risk of contracting HIV. ${ }^{137}$ However, this concept of actuarial fairness was questioned in the context of AIDS and arguably could be questioned on the same basis for genetic testing. As Norman Daniels argued, “[e]ven in insurance markets where no general social obligation is felt to

The insurance industry has long relied on family history to inform their underwriting decisions. Family history for some single gene conditions, such as Huntington's, are already being used by the insurance industry, regardless of whether applicants have undergone genetic testing or not: Weisbrot \& Opeskin, supra note 51 at 142 .

Michael Hoy \& Julia Witt, "Welfare Effects of Banning Genetic Information in the Life Insurance Market: The Case of BRCA 1/2 Genes,” (2007) 74:3 The Journal of Risk and Insurance 523 at 523. Ibid at 525 .

Ibid.

Rothstein, supra note 96 at 27.

Norman Daniels, "Insurability and the HIV Epidemic: Ethical Issues in Underwriting” (1990) 68:4 The Milbank Quarterly 497 at 520.

Ibid at 500 [emphasis in original].

Ibid at 503. See also Karen A Clifford \& Russel P Iuculano, “Aids for Insurance: The Rationale for AIDS-Related Testing” (1987) 100:7 Harv L Rev 1806 at 1816-17 (although the authors offer a different view that legislation must balance competing interests and should not force the insurance industry to bear the costs associated with AIDS). 
avail everyone of security against loss, for example, in fire or theft insurance, certain underwriting practices are considered unacceptable forms of discrimination." ${ }^{138}$ As Daniels states, "[t]he use in underwriting of stereotyped predictors of sexual orientation, or the use of sexual orientation itself, is morally unacceptable even if they prove to be actuarially accurate. Their use leads to imposing serious harms on a group that is already heavily discriminated against." ${ }^{139}$ Similar arguments are made in the context of genetics, particularly where the use of genetic testing in insurance results in discrimination against racialized and ethnic groups or women.

\section{LESSONS FROM OTHER JURISDICTIONS}

It is generally recognized that there needs to be some form of regulation on this matter. This need has been recognized on a global scale. The United Nations Universal Declaration on the Human Genome and Human Rights recognized in Article 2 that “(a) Everyone has a right to respect for their dignity and for their rights regardless of their genetic characteristics,” and “(b) That dignity makes it imperative not to reduce individuals to their genetic characteristics and to respect their uniqueness and diversity."140 Article 6 of the Declaration also prohibits genetic discrimination and Article 22 provides that "States should make every effort to promote the principles set out in this Declaration and should, by means of all appropriate measures, promote their implementation.”141 The WHO Draft Guidelines on Bioethics state that genetic information should not be used as a basis for refusing insurance. ${ }^{142}$ The Council of Europe Convention on Human Rights and Biomedicine provides that "[a]ny form of discrimination against a person on grounds of his or her genetic heritage is prohibited." ${ }^{143}$ Furthermore, Article 12 stipulates predictive genetic tests may only be performed for health purposes or scientific research. ${ }^{144}$ How have some jurisdictions responded to the use of genetic data in insurance underwriting?

\section{A. OUtright Ban}

Some jurisdictions, such as Ireland, have taken the approach of an outright ban on the use of genetic test information, seemingly agreeing with the arguments made in favour of genetic exceptionalism. ${ }^{145}$ Austria, Belgium, and Norway all have legislation prohibiting the use of genetic test results in the insurance industry, such that insurers are prohibited from requesting or using genetic information. ${ }^{146}$ This approach may be taken by itself or in conjunction with another approach, such as part of a two-tiered approach. In France, for example, insurers

138 Daniels, ibid at 510.

139 Ibid at 520 [emphasis in original].

140 Universal Declaration on the Human Genome and Human Rights, GC Res 29 C/17, UNESCO, 29th Sess (11 November 1997) Article 2, online: UNESCO <http://unesdoc.unesco.org/images/0012/ 001229/122990eo.pdf> [Declaration].

$141 \quad$ Ibid, Article 22.

142 Abdullah Daar \& Jean-François Mattei, Draft World Health Organization (WHO) Guidelines on Bioethics (1999) at s 7, online: Rechtswissenschaftiche Fakultät <http://www.rewi.uni-jena.de/ rewimedia/Downloads/LS-Ruffert/Ethical_Codes/WHO_Draft+World+HealthOrganization+ Guidelines+on+Bioethics.pdf>; Lemmens, "Selective Justice," supra note 12 at 356.

143 Convention for the Protection of Human Rights and Dignity of the Human Being with Regard to the Application of Biology and Medicine: Convention on Human Rights and Biomedicine, 4 April 1007, Eur TS 1997 No 164 (entered into force 1 December 1999), Article 11.

$144 \quad$ Ibid, Article 12.

145 Disability Act 2005, no 14 of 2005, s 42 (Ireland).

146 Lemmens, "Selective Justice," supra note 12 at 359-60. 
cannot take into account genetic test results even if voluntarily submitted. However, this may have been too aggressive an approach given the fact that there is little large-scale empirical evidence on the effect that a complete ban could have on the insurance industry. ${ }^{147}$

While this is an approach taken by several countries, there are some criticisms of this approach. One of the main criticisms is that this type of legislation does not allow insurance companies to take into account negative test results in order to overrule concerns about an applicant's family history. ${ }^{148}$ This means that individuals with a negative family history cannot dispose of their high-risk status. ${ }^{149}$ There are also arguments that this type of approach is actually unfair for other insureds because those who suffer from other medical conditions, for example high cholesterol, will not be afforded the same protection from discrimination as an applicant who is genetically at risk of developing Huntington's disease. ${ }^{150}$ This approach also raises concerns of genetic exceptionalism, as discussed above, relating to actuarial fairness and the viability of the insurance industry in the face of potential adverse selection. Further, an outright ban may create a false distinction between genetic and nongenetic tests, as discussed previously. Hence, a ban on the use of genetic test results of an applicant for insurance is of limited value if not accompanied by a prohibition on the use of family history or other information that may have the same effect on risk classification as the applicant's genetic test results. ${ }^{151}$

As well, an outright ban on the use of genetic test results in risk classifications creates a hierarchy of conditions affecting insurability resulting in unfairness among insureds. Genetic data is privileged and excluded from risk assessments, whereas other conditions affecting health and mortality rates that could also have genetic origins are considered in determining insurability. Insurers would likely attempt to circumvent an outright ban on use of genetic test results by relying on related data that can provide similar information about insurability, such as family history. A ban on reliance on genetic test results can detrimentally affect insureds who are classified as substandard risks based on family history and may, in fact, have tested negative to the genetic condition in question. Insurers cannot consider negative test results to reclassify persons with family history of genetic diseases and hence charge them standard premiums or insure them for higher amounts.

It is important to look at the underlying issues surrounding the genetic exceptionalism debate. Some of these issues include: Who in society should have access to health insurance? What is the role of private insurance in our society? What is the social purpose of life, accident, and disability insurance ${ }^{152}$ These are all issues that the genetic exceptionalism argument seeks to side-step. In order to fully address these issues, policy makers need to reconsider the role of predictive health information in society on a broader scale, not just in

Richard Walsh \& Sandy Raeburn, A Review of the Genetics Moratorium and What Might Replace It (Newbury: St Andrews Management Institute, 2009) at para 55, online: SAMI Consulting <http://www. samiconsulting.co.uk/4geneticsmoratorium.pdf>. 
regards to genetic testing. ${ }^{153}$ The questions raised in this debate may show a "need for stricter ... use of all medical information in general." ${ }^{154}$

\section{B. TWO-TIERED SYSTEM}

In Europe and elsewhere, many governments have adopted a two-tiered approach to insurance contracts that require an assessment of the applicant's health. Under a two-tiered approach, an insurer would provide access to guaranteed basic insurance coverage with no reference to genetic characteristics where the use of genetic testing is prohibited. In order to qualify for insurance exceeding this basic level, applicants may then be required to provide information related to genetic testing if they have already undergone genetic testing. Examples of this approach can be seen in Sweden, which has a two-tiered approach for both family history and genetic testing, and in the UK, which has a two-tiered system only for genetic testing. ${ }^{155}$ This approach to distinguishing between what can be classified as basic life insurance contracts and luxurious life insurance contracts benefits both applicants and insurers. It guarantees basic access to all applicants regardless of their genetic characteristics, while at the same time reducing much of the adverse selection concerns purported by the insurance industry. ${ }^{156}$ It is also important to note that in jurisdictions that have adopted a twotiered approach, such as Germany, there is generally still no requirement to undergo genetic testing.

A tiered insurance system that provides coverage for all applicants without reference to individual risk factors is consistent with the socialization of risks because everyone in the insurance pool bears some burden of those with greater risks based on an understanding of a shared sense of social responsibility. This type of system also acknowledges the brute luck of one's immutable characteristics, such as family history or genetic make-up, and may be premised on the welfare model of insurance that brings notions of social justice into arrangements within the private market. This is consistent with the view of insurance as being quasi-public funds and also the view that governance institutions, in this case insurance institutions, can be a site for distributing the benefits and burdens of social life and, hence, promoting substantive equality. Such a system is consistent with John Rawls' social contract theory that given the choice, individual policy holders would agree to basic levels of insurance without reference to factors that could affect insurability if they do not know who amongst them could be classified as substandard risk based on their genetic characteristics because anyone could potentially be classified as being a substandard risk. ${ }^{157}$ This is particularly important given the growing number of diseases that are believed to be related to genetics. ${ }^{158}$

A tiered system strikes a balance between insurance as a social good and the value of socializing risks, the commercial nature of insurance, and the importance of risk assessment in making underwriting decisions. Such a system is also premised on equality of opportunity

\footnotetext{
153 Ibid. See also Gostin \& Hodge, Jr, supra note 103 at 56-57.

154 Lemmens, "Selective Justice," supra note 12 at 377.

155 Weisbrot \& Opeskin, supra note 51 at 144.

$156 \quad$ Lemmens, Pullman \& Rodel, supra note 99 at 5.

157 See John Rawls, A Theory of Justice (Cambridge, MA: Belknap Press of Harvard University Press, 1971), ch 2.

Science and Technology Division, supra note 53 at 3.
} 
to access insurance products, at least to the extent needed to meet basic needs. Those able to manage risks through the insurance system should be able to exercise that choice in a rational way unconstrained by the brute luck of their genetic characteristics. It also avoids, or at least limits, concerns about adverse selection. ${ }^{159}$

To be fair, the socialization of risk rationale for providing basic coverage without reference to potential risk factors that can affect insurability should not be limited to genetic information. The argument in favour of promoting access to insurance as a social good is equally applicable to other factors used in risk classifications, such as health and environmental conditions.

A tiered system that supports access to a basic level of insurance without reference to the applicant's genetic characteristics raises a broader question about the purpose of insurance. If the purpose of a tiered system is to promote access to insurance as a means of accessing basic social goods such as housing, income replacement, and supplementary health insurance, then socializing risks based on the shared sense of responsibility is a legitimate social and public policy objective. However, the notion of socializing risks becomes questionable if access to insurance is being used as a means to perpetuate class stratifications and social and economic inequalities. Why should others with standard risks carry the burden of policyholders with greater or substandard risks, to assist persons in the latter group to create wealth or profit from the insurance system? For example, this may arise in relation to those who may be over-insured or who are using insurance as a means of accumulating wealth. This can be a debatable issue because life insurance, income replacement, etc. can be a means of ensuring financial security to ensure people can meet their own basic needs. At the same time, insurance is now commodified and has become an investment, a part of financial planning for future financial security, and a legitimate way of managing an individual's political economy. Viewed in this light, insurance can be a means of responsible financial planning and wealth creation beyond providing for the necessities of life in the event of disabilities, sickness, or death. The insurance system can, therefore, perpetuate unequal wealth distribution based on individuals' ability and forbearance to invest in insurance products as part of their personal economy. ${ }^{160}$ That is perhaps why the two-tiered approach also makes sense because risks will be socialized up to a certain maximum, which is hopefully consistent with what would be necessary to ensure that people's basic needs are met. Those who want greater protection or investment are entitled to do so based on a business model in which insurers may demand disclosure of specific risks to make underwriting decisions. However, the correlation between the basic insurance coverage and what is necessary to meet basic needs does not hold true in all cases. It assumes that all insureds have the same starting point. Since access to insurance for basic coverage is not means-tested, those who do not need that basic coverage to provide for the necessities of life thrift and foresight and hence personal choice for individuals. Those who exercise this "choice" are considered prudent and self-reliant whereas those who do not are perceived as lacking discipline to forgo present gratification and will likely be a burden on the state or taxpayers relief. See Bradburn $v$ The Great Western Railway Co, [1874] LR 10 Ex 1; O’Malley, supra note 2 at 128. The choice argument is not pursued in this article, however it should be noted that the choice argument is premised on formal equality and ignores the prior skewed distribution of resources that promote inequality of opportunity and access to resources. 
could still use it as a way to accumulate wealth. A person can obtain insurance from different insurers for the basic amount and cumulatively obtain coverage over and above the basic coverage regardless of their risk factor so long as they are able to pay the premium. This is possible in relation to non-indemnity insurance contracts because access to the insurance money is based on the specified or insured event happening and not proof of loss on the happening of that event. To avoid this outcome, applicants for insurance should be required to disclose existing insurance coverage for the same risk to enable insurers to determine whether an applicant for insurance has cumulatively obtained insurance above the financial limit.

Although a tiered approach seems to guarantee individuals a basic level of insurance, it raises other questions. For instance, there is no general agreement about what constitutes basic insurance coverage. There does not seem to be any uniformity regarding what level of coverage should be considered basic (for which no genetic test results should be used) and what constitutes additional or luxurious coverage which warrants the use of genetic data to determine insurability. In Germany insurers may seek results of previously conducted genetic tests, but cannot require them for policies over $€ 300,000 .{ }^{161}$ According to the moratorium in the UK, insureds will not be required to disclose the results of genetic tests for life insurance policies up to $£ 500,000$. $^{162}$

A tiered approach could reduce insurance cost, but could potentially undermine public health and increase health care costs. One of the downsides to a tiered, or ceiling, approach is that insurers can still exclude or ban certain applicants based on their family history, despite the fact that this seems to defeat the purpose of this approach to not only prevent genetic discrimination but to ensure that everyone has access to insurance which has arguably become a social necessity. ${ }^{163}$ Despite these concerns, the ceiling approach has become quite common given the fact that it greatly lowers the risk of adverse selection while still providing insurance to most members of society. ${ }^{164}$

\section{VOLUNTARY MORATORIUM}

Another mechanism to avoid genetic discrimination is through a voluntary moratorium by the insurance industry. This approach was taken in the UK, where insurers entered into the Concordat. ${ }^{165}$ It adopts a two-tiered approach to the use of genetic information in insurance underwriting, but it is a self-regulated approach as opposed to a legislative one. According to the Concordat, insurers agree to not ask applicants to undergo predictive tests, about other people's or relative's tests, to disclose results acquired through clinical research, etc. ${ }^{166}$ Section 20 of the Concordat provides:

(i) Customers will not be required to disclose the results of predictive genetic tests for policies up to $£ 500,000$ of life insurance, or $£ 300,00$ for critical illness insurance, or paying annual benefits of

Human Genetic Examination Act, Germany 2009, 374/09, § 18(1).

See Concordat, supra note 90, s 20.

Lemmens, “Genetics and Insurance Discrimination,” supra note 110 at 76.

Ibid at 75 .

Concordat, supra note 90, s 16.

Ibid. 
$£ 30,000$ for income protection insurance (the 'financial limits'). More than 97\% of policies issued in 2004 were below these limits in each category.

(ii) When the cumulative value of insurance exceeds the financial limits, insurers may seek information about, and customers must disclose, tests approved by GAIC for use for a particular insurance product, subject to the restriction in the Concordat.

In relation to part (ii) of section 20 of the Concordat and the reference to the Genetic Insurance Committee (GAIC), it is useful to note that the GAIC has only approved one application to date, which was for Huntington's disease, for life insurance policies exceeding $£ 500,000 .{ }^{167}$ Furthermore, there are no other applications currently under consideration by the GAIC. Where there is a family history of Huntington's disease, genetic testing would most likely be useful for applicants with negative results because those with a family history may be refused insurance without test results, given the high rate of family incidence.

The moratorium in the UK was created in response to concerns about genetic testing, without wanting to preclude the possibility of using these test results as part of standard underwriting practices in the future. However, some take the view that since the hypothetical situation of a large number of highly predictive new genetic tests has not materialized, the moratorium has been made a more permanent legislative option. There is still disagreement in relation to the potential future relevance of multi-factorial tests in a short time period that favour the temporary nature of the moratorium. ${ }^{168}$

The effectiveness of moratoriums remains questionable. Pursuant to the Concordat, members of the Association of British Insurers do not require applicants for insurance to disclose any genetic test results if the insurance sought is under the required amounts. ${ }^{169}$ Applicants seeking insurance above the limits need only disclose genetic test results where approved by the GAIC, although they may be required to disclose family history of genetically inherited conditions. ${ }^{170}$ However, insurers typically include the following statement in their application forms: "If you wish to disclose to us a negative genetic test result, which shows that you have not inherited a genetic disorder, we will take this into account in setting your premium, providing your clinical geneticist confirms that the test result indicates a reduced risk of developing the inherited disease.” ${ }^{171}$ It remains questionable whether a system that still allows insurers to receive test results adequately protects the interests of applicants. For example, if a person with Huntington's disease is refused on the basis of family history, they would have no choice but to be tested. This would effectively take away their decision to remain ignorant, given the necessity of insurance for many people. That was precisely the situation that an Ontario woman faced and she felt compelled to undergo testing to determine her susceptibility to Huntington's disease given that her

Gill Montia, “Condordat and Moratorium on Genetics extended,” Insurance Daily (5 April 2011), online: Insurance Daily < http://www.insurancedaily.co.uk/2011/04/05/concordat-and-moratorium-ongenetics-extended/>.

Walsh \& Raeburn, supra note 148 at para 17.

See the Concordat, supra note 90.

See Royal London - Financial Sense, "Legal Information: Genetic Code of Practice,” online: Royal London - Financial Sense <http://www.royallondongroup.co.uk/Site-Configuration/Legal-Inform ation/>.

Ibid. 
father had the condition and she was refused insurance because of that pedigree. ${ }^{172}$ Lemmens has criticized the ceiling approach, noting that it seems to violate the spirit of the moratorium where insurers still exclude applicants on the basis of family history. ${ }^{173}$ While this concern was raised in the context of the voluntary moratorium, similar concerns may arise in other two-tiered systems.

Overall, the relevant players view the moratorium in the UK as being a success. ${ }^{174}$ However, while the general consensus supports the moratorium, there are concerns, particularly in relation to the "test now, buy later" problem. The "test now, buy later" problem refers to the situation whereby people who may choose to have genetic testing done now, but do not necessarily wish to apply for life or long-term disability insurance at that point in time. ${ }^{175}$ While there is currently protection provided by the moratorium for people who get tested, if the moratorium was not extended, people who acted in reliance on the moratorium in having genetic testing may no longer be protected from disclosing these test results and may not qualify for insurance when they seek to apply for it after the moratorium has ended. Insurers point to the fact that the moratorium continues to be extended, and that, under the terms of moratorium, there would be at least a three-year period between review and the ending of the moratorium. However, this may be insufficient to quell some people's concerns. ${ }^{176}$ As a result, they may still be anxious about participating in genetic testing, which, as pointed out above, could have impacts on their personal health and on the health of society due to an unwillingness to participate in genetic research. These concerns have been voiced by the Human Genetics Commission, which argues that "the moratorium puts those thinking about undergoing testing in a very difficult position. People who undergo testing now, with the protection of the moratorium, do not know if they will be required to disclose the results when they buy insurance products in the future." ${ }^{177}$ Perhaps this concern could be addressed by inserting a retrospective rule into the moratorium to ensure that those who rely on the moratorium now in getting tested will not be required to disclose those test results after the moratorium ends. This rule could even be limited by a time period such as ten years. Other concerns exist in regards to misinterpretations of genetic data by insurers (although these seem to have been rare to date) and differential treatment of those people who have undergone genetic tests during the moratorium and those who may get tested after the moratorium has ceased to be in effect, if ever. ${ }^{178}$

Since 2001, the UK moratorium has been regularly reviewed and was recently extended until 2017. ${ }^{179}$ A review by the House of Lords Science and Technology Committee has resulted in three recommendations for the moratorium. The first recommendation is that the moratorium should include a new clause that would prevent insurers from asking for genetic

Boyle, supra note 86.

173 Lemmens, “Genetics and Insurance Discrimination," supra note 110 at 73.

174 Walsh \& Raeburn, supra note 148 at para 10.

$175 \quad$ Ibid at para 12.

176 Ibid.

177 Ruth H Wilkinson, "The Single Equality Bill: A Missed Opportunity to Legislate on Genetic Discrimination,” (2009) 3:1 Studies in Ethics, Law, and Technology 1 at 7.

178 Walsh \& Raeburn, supra note 148 at paras $11-12$

179 Department of Health, “Agreement extended on predictive genetic tests and insurance” (26 June 2012), online: Department of Health <http://www.dh.gov.uk/health/2012/06/genetics/>; Edward Hockings, “Moratorium on Insurers' use of Genetic Tests" (8 Feburary 2013), online: Ethics and Genetics <http:// www.ethicsandgenetics.org/Blog/Moratorium-on-Insurers-use-of-Genetic-Tests>; Monita, supra note 167. 
test results carried out when the moratorium was in place. This refers to the "buy now, test later" problem described above. The second recommendation was that the government and the Association of British Insurers establish a long-term agreement about the use of genetic test results in the insurance industry. Finally, it was recommended that the government should make new monitoring arrangements. ${ }^{180}$ Another recommendation identified by Walsh and Raeburn was to include regular indexing and reporting of the threshold levels above which genetic test results may be required, and the examination of the practicality of a specialized insurance market for those at risk of a single gene disorder should the moratorium cease to be in effect. ${ }^{181}$

It may also be questioned whether the insurance industry can be trusted to perform ethically on its own without regulation. This has been seen in the context of HIV/AIDS and genetic diseases such as sickle cell anemia and Tach-Says disease. A further example of this is the insurance industry's treatment of battered women in the 1990s. In the US, in the 1990s, some battered women were being denied health, disability, and life insurance coverage because these women are more likely to be victimized in the future, thus increasing their risk levels. ${ }^{182}$ This would be another example of unacceptable insurance underwriting practices despite potential actuarial fairness arguments.

While there are certainly some concerns about a voluntary moratorium, there are benefits to this approach as well. Moratoriums are temporary and provide flexibility, which may be essential given that genetic science is still evolving. ${ }^{183}$ That being said, purely voluntary regimes should not be the sole mechanism of protection as there is always the risk of nonconformists and there must be some way of ensuring compliance with these policies. Furthermore, insurers inevitably have a conflict of interest in regulating themselves and their use of genetic testing. ${ }^{184}$

The UK recently considered including genetic discrimination in the Single Equality Bill. ${ }^{185}$ However, they decided in the end that extending the moratorium would be sufficient to protect against concerns of genetic discrimination. ${ }^{186}$ There were four main reasons for the decision to not include genetic discrimination in the Single Equality Bill: (1) there was little evidence of a present problem relating to genetic discrimination; (2) the moratorium appears to be working and has been extended; (3) it was not clear that discrimination law was necessarily the best way to deal with potential problems in this area; and (4) that the Equality and Human Rights Commission would continue to take an interest in monitoring this area. ${ }^{187}$ There are criticisms that this failure to include genetic discrimination in the Single Equality Bill undermines the entire purpose of the bill, which is to simplify the law relating to equality and discrimination. ${ }^{188}$ Furthermore, it seems to make little sense to not include genetic discrimination in the Single Equality Bill on the basis that there is little evidence of genetic

Walsh \& Raeburn, supra note 148 at para 3(c).

Ibid at paras 61-62.

Deborah S Hellman, "Is Actuarially Fair Insurance Pricing Actually Fair?: A Case Study in Insuring Battered Women” (1997) 32:2 Harv CR-CLL Rev 355 at 355.

Lemmens, “Genetics and Insurance Discrimination,” supra note 110 at 59.

Ibid at 60 .

2008-2009 sess, 2009 (assented to 8 April 2010), (UK), 2010, c 15.

Wilkinson, supra note 177 at 1-2.

Ibid at 2.

Ibid at 8 . 
discrimination at present. Genetic discrimination, while arguably not as significant or severe as discrimination on the basis of sex or race, should still require proactive legislation before it becomes widespread. ${ }^{189}$ It does not make sense from an equality perspective to be purely reactionary in addressing or responding to discriminatory practices.

\section{OPTIONS FOR CANADIAN JURISDICTIONS}

Concerns regarding genetic discrimination are not new to Canada, despite the lack of legislative reform in the area. Discussion regarding genetic information, genetic discrimination, and the use of genetic testing in insurance began in the early 1990s, but nothing has materialized yet. This may be due largely to the fact that insurance is a provincial matter, as are human rights legislation relating to insurance. The Ontario Law Reform Commission recommended in 1996 a five-year moratorium on requests for genetic testing, questions about genetic conditions, and requests to access genetic information. ${ }^{190}$

However, certain steps have begun to be taken regarding the use of genetic information. While there is currently no federal legislation addressing genetic discrimination in Canada, Bill C-508 ${ }^{191}$ sought to amend the Canadian Human Rights Act ${ }^{192}$ to add genetic characteristics as a prohibited ground of discrimination. The Bill was introduced on 14 April 2010, and sought to amend section 3(1) of the Canadian Human Rights Act to include genetic characteristics as a prohibited ground of discrimination. ${ }^{193}$ While the recognition at a federal level of genetic discrimination would be significant, it would not necessarily alleviate concerns in the insurance industry which remains a provincial matter. In any event, the Bill did not get to the second reading stage.

There have been proposals to amend human rights codes in Canada to include genetic discrimination. A private member's bill was introduced in Ontario to amend the Human Rights Code to include a prohibition on discrimination on the basis of a person's genetic characteristics. ${ }^{194}$ In a statement released when the Bill received first reading, a spokesperson for the Canadian Coalition for Genetic Fairness emphasized the importance of nondiscrimination on the basis of genetic characteristics as necessary for a life of dignity. ${ }^{195}$ Despite this, it still represents little hope for the problems of genetic discrimination and insurance as it includes a proposal to add "genetic characteristics" in section 22 of the Human Rights Code, which provides an exemption for insurers. Furthermore, amending

Ibid at $10-11$.

Ontario, Information and Privacy Commissioner, supra note 77 at 4.

Bill C-508, An Act to amend the Canadian Human Rights Act (genetic characteristics), 3rd Sess, 40th Parl, 2010 (first reading 14 April 2010). Bill C-508 did not reach second reading. Bill C-536, An Act to amend the Human Rights Act (genetic characteristics), 3rd Sess, 40th Parl, 2010 (first reading 14 June 2010) was introduced a few months later as an updated version of Bill C-508 (includes a coordinating amendment) (House of Commons Debates, 40th Parl, 3rd Sess, No 62 (14 June 2010) at 3773 (Bill Biksay)). Bill C-536 did not reach a second reading before the 40th Parliament was dissolved.

RSC 1985, с H-6.

Bill C-508, supra note 191, s 1.

Bill 199, An Act to amend the Human Rights Code with respect to genetic characteristics, 2nd Sess, 39th Leg, Ontario, 2011 (first reading 18 May 2011). The Bill did not get to second reading. A similar Bill was introduced at the federal level in 2010 but died with the call for election in 2011 (House of Commons Debates, 40th Parl, 3rd Sess, No 25 (14 April 2010) at 1510 (Judy Wasylycia-Leis)).

See “MPP Introduces Bill to Amend Human Rights Code," online: Mike Colle MMP <http://www. mikecolle.com/DocumentEN.aspx?id=54> (statement by Bev Heim-Myers on behalf of the Canadian Coalition for Genetic Fairness). 
human rights codes to include prohibition on the basis of genetic characteristics in the context of insurance would not necessarily preclude the use of such information in making underwriting decisions. Given the nature of insurance contracts as being necessarily based on risk assessment, insurers are exempt from making distinctions based on prohibited grounds where there are reasonable and bona fide grounds for doing so.

There are presently no laws in Canada regulating the use of genetic test results in insurance underwriting. Initiatives toward regulation so far have been in the form of proposed private members' bills that have not made it through the legislative process. There may be pressure for Canadian jurisdictions to regulate the use of genetic test results in insurance underwriting as testing become more widespread and affordable and in light of the US 2008 federal Genetic Information Non-Discrimination Act. ${ }^{196}$ Michael Hoy and Julia Witt have suggested that one option for Canadian jurisdictions would be to enter into a moratorium, as has been done in the United Kingdom. ${ }^{197}$ It has been suggested that a shortto medium-term moratorium may be more desirable than strict legislation prohibiting genetic discrimination because it may be difficult to change such legislation. ${ }^{198}$ While the use of genetic test results in the insurance industry may not be desirable at this point in time, in the future adverse selection concerns may increase. This would include a "no questions asked" policy, up to a specified amount. ${ }^{199}$ This recognizes the fact that "[t]he very nature of private insurance legitimates discrimination. However, a basic disability or life insurance for all applicants with 'no questions asked' could provide minimum coverage to everyone and avoid problems of discrimination. Additional coverage could be dependent on an agreement by the applicant to be tested for genetic disorders." ${ }^{200}$ Rothstein recognizes that support for general legislation may be hard to find, which is why there is the tendency to favour genetic-specific legislation. However, if genetic-specific legislation is passed, he argues that this must be perceived as a stepping stone and that genetic exceptionalism is not the ideal. ${ }^{201}$

\section{ConCLusion}

Insurance underwriting necessarily entails actuarial discrimination given that a correlation between a person's risk factors and the terms of the insurance policy including premiums and insurance amount are essential for the viability of the insurance industry. The bases for determining insurability may conflict with human rights values, for example where insurers rely on prohibited grounds of discrimination in their underwriting decisions. In Zurich, the Supreme Court of Canada noted that while business expediency per se should not trump human rights values, it also recognized that actuarial discrimination on prohibited grounds may be justifiable where it is based on reasonable and bona fide grounds and insurers have no practical alternative to using that system. ${ }^{202}$ It is standard practice for insurers to rely on health status and future health risks, including family history, in determining insurability for policies that provide protection for health and mortality risks. The increasing availability of genetic testing for therapeutic and non-therapeutic purposes is providing insights into the

\footnotetext{
$196 \quad$ Lemmens, Pullman \& Rodal, supra note 99 at 1.

$197 \quad$ Hoy \& Witt, supra note 131 at 544.

198 Ibid.

$199 \quad$ Ibid at 525, 544.

200 Law Reform Commission of Canada, supra note 38 at 50.

201 Rothstein, supra note 96 at 31-32.

$202 \quad$ Supra note 39 at 349.
} 
health status and future health risks of individuals, families, and entire groups. There are now questions about the appropriateness of insurers' reliance on genetic information for underwriting purposes in the same way as health information and family history to determine a person's health status and to predict their future health risk.

There are a number of concerns regarding reliance on genetic information for underwriting purposes. There are questions about what constitutes genetic testing and the accuracy of information obtained from the process. There are debates among scientists, insurers, and the general public about what constitutes genetic information and whether it is qualitatively different from other health and pedigree information that is considered for insurability purposes. Further, there are questions about the predictive value of genetic information, which is at best probabilistic. While the predictive value may be higher for monogenetic conditions such as Huntington's disease, the same cannot be said of poly-genetic conditions. As well, focusing on genetic characteristics as a predictor of future health status ignores the multi-factorial origins of diseases, including environmental and lifestyle, and leads to a deterministic view of genetic characteristics. This practice reflects what has been described as the "availability heuristic" to justify using available genetic information in insurance underwriting because the risk may materialize for some persons with particular genetic markers, although the predictive value may not justify insurers' concerns. ${ }^{203}$

While insurers will not directly make genetic testing a precondition for insurability, an applicant for insurance is obliged to disclose any genetic information within their actual or constructive knowledge that can affect insurability or risk breach of the disclosure duty. There have been calls for a ban on reliance on genetic information in determining insurability because, among other things, such information is unique and reveals health information not only about the individual subject but others such as their family and entire groups, although health information and family history continue to be valid bases for underwriting decisions. There is no consensus among scientists in favour of genetic exceptionalism even in the context of the patient-physician relationship or more generally among health professionals to warrant differential treatment of genetic information compared to other health information. Arguments against genetic exceptionalism are justified, inter alia, based on the difficulties of determining what constitutes genetic information and the fact that the same information may be obtained from health information and family history that do not appear to enjoy the heightened protection that some are willing to accord to genetic information. The distinction is even more difficult to justify in the insurance context where actuarial discrimination on the bases of health status and family history are accepted underwriting practices. As the Nuffield Council on Bioethics points out, it will be unreasonable to restrict access to genetic information while factors that may be equally indicative of a person's health status such as family history and other health information continue to be used in risk assessment. ${ }^{204}$ The focus should rather be on getting insurers to appreciate what constitutes genetic information and the predictive value of such information to help them make accurate predictions about a person's future health risks and avoid erroneous interpretation of test results. As well, attention needs to be given to the setting in which testing was conducted, for example 
whether it was a direct to consumer testing, as a research subject, or by a health professional. Genetic information should be used only where the test is approved to be safe, effective, and there is evidence of its utility. Some gene mutations have incomplete penetrance and as such, some individuals with those mutations may never develop the disease, although it may be impossible to separate that group from those who carry the particular gene mutation. ${ }^{205}$ This is not a reason for genetic exceptionalism but rather a probabilistic risk assessment based on the chances of persons with those genes developing particular health conditions, bearing in mind the multi-factorial causes of diseases and the fact that a positive test result will often not be enough to reveal if and when the individual might develop the condition, the severity, and how they might respond to treatment.

It is not unreasonable to make underwriting decisions based on the chances of the insured risk materializing for people with particular risk factors even if they are asymptomatic. The probabilistic approach is consistent with the risk spreading rationale underlying insurance to ensure persons who face a common risk bear their fair share of that risk materializing. It also entails socializing risks to some extent because persons with higher risk factors are not necessarily precluded from accessing insurance products, although they may have to pay higher premiums that are consistent with their risk level. Ultimately, some form of legislation regulating the use of genetic information in insurance underwriting could provide an effective solution. The legislative framework should balance the competing interests to ensure access to basic levels of insurance as a public policy goal while at the same time ensuring the viability of the insurance system. 